\title{
Comment
}

\section{Successorship Under Howard Johnson: Short Order Justice For Employees}

\author{
James Severson ${ }^{\dagger}$ \\ Michael Willcoxon ${ }^{\dagger \dagger}$
}

\begin{abstract}
In Howard Johnson Co. v. Detroit Local Joint Executive Board, the Supreme Court held that a successor employer has no obligation to arbitrate under his predecessor's collective bargaining agreement absent substantial continuity in the identity of the work force across the change in ownership. The authors of this Comment examine the development of the successorship doctrine and argue that the Howard Johnson rule fails to strike the proper balance between the interests of employers and those of employees in light of the social policies underlying both the successorship doctrine and the National Labor Relations Act. The authors also explore the inadequacies of the alternative means by which insiders may protect their interests in the successorship situation following Howard Johnson.
\end{abstract}

In Howard Johnson Co. v. Detroit Local Joint Executive Board, ${ }^{1}$ the United States Supreme Court held that federal labor law imposes no obligation on a "successor" ${ }^{2}$ to submit to arbitration under a predecessor's collective bargaining agreement absent "substantial continuity" in the identity of the work force across the change in ownership. ${ }^{3}$ The

$\dagger$ B.S. 1967, M.S. 1968, Stanford University; J.D. 1975, Boalt Hall School of Law; Law Clerk to Judge Samuel Conti, United States District Court for the Northern District of California.

t† B.A. 1972, University of California, Berkeley; third-year student, Boalt Hall School of Law.

The authors wish to acknowledge the constructive criticism and substantive suggestions of Professor David Feller of the Boalt Hall faculty.

1. 417 U.S. 249 (1974).

2. The term "successor" has become a term of art. Every new employer taking over an existing business is a successor in the literal sense, but courts have fashioned a more restrictive definition. For legal purposes, a "successor" is an employer which, because it has left operations substantially unchanged in the employing enterprise it has acquired, is held by federal labor law to be subject to some of the same duties and obligations in the area of labor relations as was its predecessor. E.g., NLRB v. Burns Int'1 Security Servs., Inc., 406 U.S. 272 (1972).

3. At no point did the Court define "substantial continuity" in terms of a mathematical percentage. It did, however, favorably refer to the "emphasis most of the lower 
new employer may be required, under the federal labor law doctrine of "successorship," to adhere to some substantive provisions of an unexpired collective bargaining agreement between the predecessor and the union if a majority of the predecessor's employees have been retained. The extent to which the substantive terms of the agreement "survive" the change in ownership will be determined by an arbitrator pursuant to the prior agreement's arbitration provision, a substantive provision which always survives if the necessary work force continuity exists. On the other hand, the successor is free of all obligations under the predecessor's collective agreement if the requisite number of employees is not retained.

In Howard Johnson, the new employer had selected only a handful of the prior workforce for continued employment. The unions representing the predecessor's employees desired to arbitrate various issues arising from the takeover, particularly the issue whether the terminated employees could assert any right to employment against the successor. The prior agreement expressly provided that it would "be binding upon the successors, assigns, purchasers, lessees or transferees of the Employer . . . provided the establishment remains in the same line of business." 4 Despite the provisions of the prior contract and despite the continuity of operations, ${ }^{5}$ the Supreme Court held that the new employer had no duty to arbitrate the extent of its obligations to the employees of the prior owner. ${ }^{6}$

The effect of this holding is to grant the purchaser of a business the unilateral power to terminate any collective bargaining agreement governing the business operation simply by limiting the number of the predecessor's employees hired. ${ }^{7}$ In the process, the new owner also has the power to determine whether unionization of the enterprise will continue for the immediate future.

courts have placed on whether the successor employer hires a majority of the predecessor's employees . . . " 417 U.S. at 263-64 (1974). Courts since have read the Howard Johnson case as not mandating a simple "majority" rule. Boeing Co. v. International Ass'n of Machinists \& Aerospace Workers, 504 F.2d 307 (5th Cir. 1974).

This Comment rejects attempts to establish a numerical prerequisite for finding successorship. Rather, the authors believe that issue should be determined by examining the continuity-pattern of only those factors that would provide an objective index of "substantial continuity." See Part II infra.

4. 417 U.S. at 266 n.1.

5. Justice Douglas, dissenting, characterized this complete continuity by stating: "The business continued without interruption at the same location, offering the same products and services to the same public, under the same name and in the same manner ...." Id. at 267.

6. Id. at 264-65. For a detailed description of the facts of the case and the manner in which it was brought to the Supreme Court, see Part II infra.

7. Id. at 261-62. 
This Comment considers whether the holding in Howard Johnson strikes the proper balance between the interests of employers and those of employees in light of the social policies underlying both the National Labor Relations Act ${ }^{8}$ and the federal doctrine of successorship. Part I traces and analyzes the case law development of the successorship doctrine prior to Howard Johnson, isolates the interests the doctrine was devised to protect, and identifies the legal tests formulated to assure a proper balance between competing interests. Then, following a description of the opinion itself, the historical background is employed in Part II: (1) to suggest specifically that Howard Johnson represents an unwarranted contraction of the successorship doctrine; and (2) to argue generally that the interests of employees in retaining their jobs should be accorded greater weight in defining the scope of employer obligations in successorship situations. Part III explores the adequacy of possible alternative means by which unions may protect their interests after the restrictive treatment of the successorship doctrine in Howard Johnson.

\section{Legal BACKGROUND OF THE SUCCeSSORSHIP DOCTRINE}

\section{A. The Successorship Doctrine Emerges: the Wiley Case}

The leading case in the development of the doctrine of successorship is John Wiley \& Sons, Inc. v. Livingston. ${ }^{9}$ The union sought, in a suit brought under section 301 of the Labor Management Relations Act, ${ }^{10}$ to compel a successor (Wiley) to arbitrate under an extant collective bargaining agreement with the predocessor (Interscience), after Interscience had been merged into Wiley and had ceased to do business as a separate entity. The collective bargaining agreement contained no express provision making it binding on successors of Interscience, ${ }^{11}$ and Wiley had neither expressly nor impliedly consented

8. 29 U.S.C. $\$ \$ 151-68(1970)$.

9. 376 U.S. 543 (1964).

10. Section 301(a) of the Labor-Management Relations Act, grants federal courts jurisdiction, without regard to either the amount in controversy or the citizenship of the parties, to entertain "[s]uits for violation of contracts between an employer and a labor organization representing employees in an industry affecting commerce ..." 29 U.S.C. $\$ 185(a)(1970)$.

11. Such a contractual provision is commonly referred to as a "successorship clause." Although the clause often states that a successor "shall be bound" to the contract, it does not legally bind the non-contracting successor. The provision has two purposes: (1) it provides evidence of the contracting parties' intent regarding the effects of changes in ownership of the business; see, e.g., Detroit Local Joint Exec. Bd. v. Howard Johnson Co., 482 F.2d 489, 493 \& n.9 (6th Cir. 1973); and (2) more significantly, it may provide the legal basis for an injunction or a suit for breach of contract against a predecessor who fails to obtain the successor's express agreement to abide by the collective agreement; see text accompanying notes 196-204 infra. 
to recognize the existing union or the existing agreement. All of Interscience's employees were offered employment by Wiley and, for a time after the merger, those accepting positions continued to perform their duties at the same plant location. The Interscience plant was later closed and the former Interscience employees were integrated into a larger work force at a new plant location.

Beyond asserting that Wiley had a duty to arbitrate, the union urged specifically that Wiley was obligated to respect the Interscience employees' seniority rights accumulated under the premerger contract with Interscience, to abide by the contract's job security and grievance provisions, to make contributions to the union pension fund, and to provide vacation pay and severance pay in amounts specified in the contract. These rights, the union claimed, had "vested" during the term of the Interscience agreement and could not be withdrawn merely because corporate ownership had changed. Wiley, on the other hand, pointed out that it was not a party to the contract which created the asserted rights and that no authority existed for holding it bound to a contract under the facts.

The Supreme Court held that the successor was required to arbitrate, reasoning that:

[T] he disappearance by merger of a corporate employer which has entered into a collective bargaining agreement with a union does not automatically terminate all rights of the employees covered by the agreement, and . . . in appropriate circumstances, present here, the successor employer may be required to arbitrate with the union under the agreement. ${ }^{12}$

The circumstances were "appropriate," the Court noted, where there was "similarity and continuity of operation across the change of ownership." 13 In an attempt to distinguish those situations in which the imposition of the duty to arbitrate was "appropriate" from those in which it was not, the Court used a fiction based, in part, on party expectations:

[T] here may be cases in which the lack of any substantial continuity of identity in the business enterprise before and after a change would make a duty to arbitrate something imposed from without, not reasonably to be found in the particular bargaining agreement and the acts of the parties involved. ${ }^{14}$

12. 376 U.S. at 548.

13. Id. at 551 . The Court found that the relevant "similarity and continuity of operation . . . [was] adequately evidenced by the wholesale transfer of Interscience employees to the Wiley plant, apparently without difficulty." Id.

14. Id. One commentator characterizes this statement as "sheer rhetoric," noting that "[t]he duty to arbitrate, as applied to the nonconsenting successor, is always imposed from without." Goldberg, The Labor Law Obligations of a Successor Employer, 
Referring to the "preference of national labor policy for arbitration as a substitute for tests of strength between contending forces," ${ }^{16}$ the Court observed that resolution of the issue must turn on a careful balancing of private as well as public interests:

The objectives of national labor policy . . . require that the rightful prerogative of owners independently to rearrange their businesses and even eliminate themselves as employers be balanced by some protection to the employees from a sudden change in the employment relationship. The transition from one corporate organization to another will in most cases be eased and industrial strife avoided if employees' claims continue to be resolved by arbitration . . . .18

The Court held that Wiley was bound to arbitrate grievances under the collective bargaining agreement and that the arbitrator was to decide which contractual provisions survived the change of ownership. ${ }^{17}$

\section{The Collective Bargaining Agreement as the "Common Law" of the Plant}

An important aspect of Wiley was the Court's refusal to treat the collective bargaining agreement as an ordinary contract. Instead of contract rules, federal labor law and its underlying policies controlled. ${ }^{18}$ Although principles of contract law might preclude binding the noncontracting successor, the Court reasoned that the collective bargaining agreement "is not an ordinary contract . . . . it is a generalized code to govern a myriad of cases which the draftsmen cannot wholly anticipate ... [i]t calls into being a new common law-the common law of a particular industry or of a particular plant." "19 The peculiar nature of

63 Nw. U.L. Rev. 735, 747 (1969). The focus on enterprise continuity, rather than on a showing that the successor intended or impliedly consented to be bound to arbitrate, supplies the justification, in light of relevant individual and national interests, for legally imposing the duty to arbitrate on the successor.

15. 376 U.S. at 549.

16. Id.

17. Id. at $550-51,554-55$.

18. Id. at $548,550-51$.

19. Id. at 550, quoting United Steelworkers v. Warrior \& Gulf Navigation Co., 363 U.S. 574, 578-79 (1960). The Court also stated that the collective bargaining agreement "is not in any real sense the simple product of a consensual relationship." Id. Professor Feller has pointed out the dissimilarities between the collective agreement and an ordinary contract. Two of the most notable are: (1) that the collective agreement governs the terms and conditions of employment of the minority of employees in the bargaining unit who did not support the union as bargaining representative and who may not wish to be bound by the collective agreement, as well as those employees who were hired after the agreement was made and therefore had no chance to participate in negotiating its terms; and (2) that once employees select a bargaining representative, the employer is required by law to bargain with that representative in good faith, even though the particular union may not have been its personal choice. Feller concludes that the collective bargaining agreement "is not simply a voluntary contractual arrange- 
a collective bargaining agreement is most evident in the fact that implicit duties are commonly inferred from the interstices of express terms, whereas such duties are seldom implied from ordinary contracts. ${ }^{20}$

Once established, this "common law" gains a certain momentum of its own and its preservation serves public as well as private interests. The public interest in encouraging peaceful industrial relations is promoted by preserving the existing collective bargaining agreement. Economic stability, at least in the short-run, is a product of the preservation of the extant agreement. A change in corporate ownership that does not in any concrete way change conditions in the plant should not override the employees' perception of a legitimate claim to continued employment. ${ }^{21}$ It was to protect these interests that the successorship doctrine was developed. ${ }^{22}$

Wiley supported the interests protected by the "common law" of the plant. Although the case may be read narrowly, it has been read as implicitly recognizing that so long as substantial continuity of operations is maintained, the collective agreement should continue to govern employer-employee relations. ${ }^{23}$

ment. . . . It is, rather, a set of rules, established in accordance with procedures prescribed by the National Labor Relations Act, and intended to promote industrial peace and stability in the bargaining unit which it covers." Feller, Status of the Collective Bargaining Agreement Under Wiley v. Livingston: A Union Counsel's View, in ProCEedings of New York University Erghteenth ANNUAL Conference on Labor 277, 278-79 (1966). The words of the Supreme Court provide ample support for this viewpoint: "[A] collective bargaining agreement is an effort to erect a system of industrial self-government." United Steelworkers v. Warrior \& Gulf Navigation Co., 363 U.S. 574, 580. (1960).

20. See United Steelworkers v. Reliance Universal Inc., 335 F.2d 891 (3d Cir. 1964).

21. See, e.g., NLRB v. Armato, 199 F.2d 800, 803 (7th Cir. 1952); Cruse Motors, Inc., 105 N.L.R.B. 242, 247 (1953). And see text accompanying notes 156-74 infra.

22. John Wiley \& Sons, Inc. v. Livingston, 376 U.S. 543, 549 (1964).

23. See Feller, supra note 19, at 283. Professor Feller found implicit in the Wiley holding the broader conclusion that the successor was bound by the collective agreement. He contended that this result was the logical concomitant of the Court's holding that Wiley could not be required to arbitrate grievances under the Interscience collective agreement unless it was bound by that agreement. As the Court stated in Wiley:

The duty to arbitrate being of contractual origin, a compulsory submission to arbitration cannot precede judicial determination that the collective bargaining agreement does in fact create such a duty. Thus, just as an employer has no obligation to arbitrate issues which it has not agreed to arbitrate, so a fortiori, it cannot be compelled to arbitrate if an arbitration clause does not bind it at all.

376 U.S. at 547. From this statement Professor Feller concluded that:

There seems to be little basis . . . for reading Wiley somehow as leaving to arbitration the question of whether the successor is bound or limiting the rule of the case to agreements containing an arbitration provision. Even if there had been no arbitration provision in the Interscience agreement, Wiley would nevertheless have become bound by the agreement at the time it acquired the Interscience business. 


\section{Post-Wiley Development of the "Continuity of Interest" Test}

Later cases involving suits to enforce arbitration clauses in the successorship context have read the holding of Wiley broadly, sometimes demanding that the successor adhere to the specific terms of the agreement. In Wackenhut Corp. v. Plant Guard Workers Union ${ }^{24}$ the Ninth Circuit Court of Appeals held that a predecessor's collective bargaining agreement, including the arbitration clause, was binding upon a successor that had purchased all the assets, hired all the employees, carried on the same business under the same trade name, and intended to assume all the contracts of the predecessor except the collective agreement.

In United Steelworkers $v$. Reliance Universal Inc., ${ }^{25}$ the Third Circuit Court of Appeals adopted an approach that epitomizes judicial recognition of the flexibility of arbitration. It held that the collective agreement was the "basic charter" of labor relations in the plant and that it therefore presumptively bound a successor that had purchased the business assets and had continued operations substantially unchanged. The court added, however, that "new circumstances created by the acquisition of a business by a new owner may make it unreasonable or inequitable to require labor or management to adhere to particular terms of a collective bargaining agreement previously negotiated by a different party in different circumstances."26 Thus, inequity was to be avoided by allowing an arbitrator hearing a particular dispute to consider any relevant new circumstances and to direct an award "at variance with some term or terms of [the] contract" if necessary to achieve a "just and equitable settlement of the grievance at hand."27

\section{B. The Successorship Doctrine of the National Labor Relations Board and Before the Supreme Court}

Meanwhile, the development of the successorship doctrine had been proceeding apace in the National Labor Relations Board INLRB, or Board] ${ }^{28}$ Prior to Wiley, the Board had been called upon in several cases to issue a bargaining order against a successor that had refused to recognize and bargain with the preexisting union. ${ }^{29}$ As early as 1948

Feller, supra note 19, at 283. Contrast the Supreme Court's ultimate resolution of the issue of the successor's duty to abide by the contract in toto in NLRB v. Burns Int'l Security Servs., Inc., 406 U.S. 272 (1972), and see text accompanying notes 88-92 infra.

24. 332 F.2d 954 (9th Cir. 1964).

25. 335 F.2d 891 (3d Cir. 1964).

26. Id. at 895 .

27. Id.

28. For a discussion of the effects of changes in the employing unit, see C. MORRIS, The DeVeloping LABOR LAw ch. 13 (1971).

29. See, e.g., Maintenance, Inc., 148 N.L.R.B. 1299 (1964); Johnson Ready Mix Co., 142 N.L.R.B. 437 (1963); Stonewall Cotton Mills, 80 N.L.R.B. 325 (1948). 
the Board had formulated a test, much like the "substantial continuity" test which later appeared in Wiley, whereby if "no essential attribute of the employment relationship"30 had been changed by the transfer of ownership, the successor was under a legal duty to recognize and bargain with the union representing the predecessor's employees.

In Stonewall Cotton Mills, ${ }^{31}$ the National Labor Relations Board had allowed a union to amend its recent certification as bargaining representative by substituting the name of the successor-employer for that of the predecessor, thus bringing the successor within the federally imposed obligation to bargain. The Board noted that the successor had purchased all assets of the predecessor, had continued to manufacture the same product with the same plant, equipment and production methods, and had retained the predecessor's entire work force. Finding that no "essential attribute" had changed, the Board held that the certification continued to represent the will of the employees with respect to their choice of bargaining representative and, therefore, the obligation to bargain continued in force against the successor. ${ }^{32}$ In granting the union's motion to amend, the NLRB stated that the motion "seeks no more than to make explicit the successor-employer's already existing obligation to bargain." ${ }^{33}$ This quoted passage made clear that the duty to bargain "attached to" the bargaining unit taken over by the successor with the enterprise, and not to the particular employer who happened to participate in the certification. As long as the enterprise remained essentially unchanged, the duty to bargain survived despite the change in ownership. ${ }^{34}$

A like result was reached in Maintenance $1 n c .{ }^{35}$ decided the same year as Wiley, in which the successor was found to have violated section $8(a)(5)$ of the National Labor Relations $\mathrm{Act}^{36}$ by refusing to bargain with the union representing the predecessor's employees. The successor, whose competitive bid for a contract to render janitorial services to

30. Stonewall Cotton Mills, 80 N.L.R.B. 325,327 (1948).

31. 80 N.L.R.B. 325 (1948).

32. Id. at 327.

33. Id. at 328 (emphasis added).

34. See also Johnson Ready Mix Co., 142 N.L.R.B. 437, 442 (1963).

35. 148 N.L.R.B. 1299 (1964).

36. Section $8(a)(5)$ provides that it is an unfair labor practice for an employer "to refuse to bargain collectively with the representatives of his employees . . . 29 U.S.C. $\& 158(a)(5)(1970)$. The duty to bargain is defined in section $8(d)$ of the Act as follows:

[T]o bargain collectively is the performance of the mutual obligation of the employer and the representative of the employees to meet at reasonable times and confer in good faith with respect to wages, hours, and other terms and conditions of employment, or the negotiation of an agreement, or any question arising thereunder ....

29 U.S.C. $\$ 158$ (d) (1970). 
the National Aeronautics and Space Administration had been accepted over the predecessor's, argued that since he had not purchased assets or dealt with the prior supplier of services in any other way, he was not a "successor" subject to the statutory duty to bargain. A majority of the Board rejected this contention, stating:

[W] do not view [the buyer's not having purchased physical assets of the seller] as a substantial basis for distinction in applying the fundamental principle involved. The duty of an employer who has taken over an "employing industry" to honor the employees' choice of a bargaining agent is not one that derives from a private contract . . . . It is a public obligation arising by operation of the Act. The critical question is not whether [the successor] succeeded to [the predecessor's] corporate identity or physical assets, but whether [the successor] continued essentially the same operation, with substantially the same employee unit whose duly certified bargaining representative was entitled to statutory recognition at the time [the successor] took over. ${ }^{37}$

The Board stressed the fact that the successor "assumed the obligation the Act imposes" to bargain with the union when it voluntarily selected the employees of the predecessor as its work force to perform the same tasks at the same location. ${ }^{38}$ The obligation to recognize and bargain with the chosen representative attached to the bargaining unit, and it had remained intact across the change in ownership.

In each of the foregoing Board cases, the "essential attribute" of work force identity before and after takeover was present-a clear majority of the successor's work force consisted of the predecessor's employees, voluntarily hired by the successor. ${ }^{39}$ The duty to bargain

37. 148 N.L.R.B. at 1301 (emphasis added). Member Leedom, while concurring in the majority's conclusion that the employer had violated section $8(a)(5)$, reached this result on the grounds that the employer had no reasonable doubt with respect to the union's status as representing a majority of the employees. He rejected the majority's conclusion that the employer was a successor of the prior contracting employer, stressing both that the employer neither acquired any assets nor assumed any liabilities of the prior employer and that there was no relationship between the two firms. He emphasized that, in contrast to this case, all prior cases in which the Board had found a new employer to be a "successor" such as to be subject to the duty to bargain, there had always been some legal relationship between the successor and the predecessor. 148 N.L.R.B. at 1306-07. Compare this viewpoint with that of the Supreme Court in NLRB v. Burns Int'l Security Servs., Inc., 406 U.S. 272 (1972) (see text accompanying note 93 infra), and particularly with the viewpoint expressed by Justice Rehnquist in a separate opinion in that case (see text accompanying notes $97-99$ infra).

38. 148 N.L.R.B. at 1302.

39. Note that failing to hire a majority of the predecessor's employees does not, in itself, relieve a successor from the bargaining obligation. If, for example, the number of the predecessor's employees hired by the successor constitutes a majority of the successor's work force, the successor may be obligated to bargain even though it may not have hired a numerical majority of its predecessor's employees. See, e.g., Makela Weld- 
attached to the previously certified unit. The protected employee interest was preservation of the chosen representative without the burden of having to reinstitute certification proceedings with each change of ownership. ${ }^{40}$ No question was presented in these cases as to what bargaining duty, if any, might arise where the successor did not retain the former employees, nor did the cases establish what the buyer's obligations were with respect to recognizing the substantive terms of the predecessor's collective agreement in situations where the former employees were retained.

\section{The Chemrock Doctrine}

A partial answer to the first of these questions appeared in Chemrock Corp. ${ }^{41}$ decided by the National Labor Relations Board 1 year after Wiley. The successor-employer intended to operate a manufacturing business in essentially the same manner as had its predecessor. It proposed to retain its predecessor's five drivers, constituting a single bargaining unit, on the condition that they accept a wage cut. The union was excluded from the discussions between the successor and the drivers. The drivers declined the offer, demanded that their union be allowed to represent them, and insisted on the wage rate under the prior contract. The successor then hired other drivers at the lower rate, and the union filed suit under, among other sections, section 8(a)(5) of the National Labor Relations Act. In the proceedings before the NLRB, the successor contended that no section 8(a)(5) duty to bargain existed because the complaining workers had not been hired by it and, therefore, were not its "employees" within the meaning of the section.

The NLRB disagreed with the successor-employer, holding that the drivers were "his employees" and, therefore, his refusal to bargain with the union, his unilateral change in wage rates and his attempt to deal individually with the workers were unfair labor practices in violation of section $8(\mathrm{a})(5) .^{42}$ In reaching its decision the Board relied on a series

ing Co. v. NLRB, 387 F.2d 40, 46 (6th Cir. 1967); NLRB v. Armato, 199 F.2d 800, 803 (7th Cir. 1952); General Elec. Co., 173 N.L.R.B. 511 (1968); Western Freight Ass'n, 172 N.L.R.B. 303 (1968). And see Goldberg, supra note 14, at 793-94.

40. In Maintenance, Inc., 148 N.L.R.B. 1299 (1964), the Board pointed out that such protection was even more imperative for employees in services industries where supply contracts are often short-term:

It would be virtually impossible for employees to achieve collective-bargaining rights in an employing industry which is periodically subject to a possible change of employers if with every change the employees must again resort to the Board's processes in order to demonstrate anew their desire to be represented by their formerly certified bargaining representative. Id. at 1302.

41. 151 N.L.R.B. 1074 (1965).

42. Id. at 1080. The successor was held also to have violated section $8(a)(1)$. which makes it an unfair labor practice for an employer "to interfere with, restrain, or 
of cases in which the Supreme Court had held that the term "employees" was to be construed broadly, without regard to "technical concepts" of the employer-employee relationship. ${ }^{43}$ In one of the cases relied upon by the Board, the Court had simply said that "[w]here all the conditions of the relation require protection, protection ought to be given."44 Applying this test, the Board found that in Chemrock the relation between the successor and the individuals employed by the seller of the enterprise required protection:

Such individuals possess a substantial interest in the continuation of their existing employee status, and by virtue of this interest bear a much closer economic relationship to the employing enterprise than, for example, the mere applicant for employment [recognized to be an "employee" for purposes of the Act] in the Phelps Dodge case. ${ }^{45}$

The Board then concluded that "clearly employees in such a situation are entitled to seek through bargaining to protect their economic relationship to the enterprise that employs them." ${ }^{36}$ The Board ordered Chemrock to reinstate the predecessor's employees with back pay, and also ordered Chemrock to bargain with the union.

Chemrock established that, absent a substantial change in the business enterprise across the change of ownership, the predecessor's employees were the "employees" of the successor for purposes of the statutory duty to bargain. This designation applied even if the successor had not actually taken these employees into its own employ and did not desire to do so. The Board made it clear, however, that the holding meant only that the successor must bargain with the union about the status of these employees:

We do not hold, as Member Jenkins [dissenting] suggests, that the purchaser of an enterprise is legally obligated to refrain from making any changes in the employment status of his predecessor's employees or to continue their employment under existing terms and conditions of employment. Rather we hold that . . . the purchaser may not ignore the employees' collective-bargaining representative in dealing with them as to matters related to the continuation of their employment and the terms and conditions of such employment. ${ }^{47}$

coerce employees in the exercise of rights guaranteed in section 7." 29 U.S.C. $\S 158$ (a) (1) (1970). The Board specifically found interference with the section 7 right of the employees to bargain through their designated representative. 151 N.L.R.B. at 1080-88.

43. See, e.g., NLRB v. Hearst Publications, Inc., 322 U.S. 111 (1944); Phelps Dodge Corp. v. NLRB, 313 U.S. 177 (1941).

44. NLRB v. Hearst Publications, Inc., 322 U.S. 111, 129 (1944), quoting Lehigh Valley Coal Co. v. Yensavage, 218 F. 547, 552 (2d Cir. 1914).

45. 151 N.L.R.B. at 1078 (emphasis added).

46. Id.

47. Id. at $1080 \mathrm{n} .8$. 
Until the successor had negotiated a new agreement or bargained to an impasse, the terms and conditions of the existing contract were to remain in effect, and the successor could not unilaterally change them without violating section 8(a)(5). The successor was thus treated the same as would be any employer in the process of negotiating a new agreement with employees. By holding that the predecessor's employees were the successor's employees for purposes of the duty to bargain, the Board imposed the terms and conditions of the existing contract with the predecessor on the successor for the period prior to and during negotiations.

\section{The Chemrock Doctrine Analyzed}

The Chemrock doctrine thus effected a compromise between the rights of the employees and those of the successor. The successor was protected in that it was not necessarily obligated to retain its predecessor's employees or abide by the terms and conditions of its predecessor's collective bargaining agreement for its stated duration. If negotiations resulted in an impasse and a strike ensued, the employer could hire replacements on its own terms and conditions. ${ }^{48}$ At the same time, the rights of the predecessor's employees were protected in that the successor was required to negotiate with their union, and, while negotiations were proceeding, it was obligated to abide by the terms and conditions of its predecessor's collective agreement. It was subject to these obligations whether or not it had actually taken these workers into its employ. Thus, the substantive protection of the workers' interests was not initially contingent upon the successor's unfettered choice.

There are at least three reasons why this resolution of the competing interests was unacceptable, however. First, the Board's finding of "employee status" was premised on the employees' substantial interest in the continuation of their existing employee status, their close economic relationship to the employing enterprise, and their inability to protect themselves from changes in the employment relationship brought about by changes in ownership. ${ }^{48}$ These employee interests warrant greater protection than the Chemrock doctrine affords. Under Chemrock, an employer wishing to terminate employees or decrease their wages need simply go through the ritual of bargaining to impasse. Second, it is inconsistent to hold that the predecessor's employees are the successor's employees while allowing the successor to alter the terms and conditions

48. Apparently, the successor could, after bargaining to impasse, hire its predecessor's employees under terms and conditions at variance with the prior contract, as long as it had complied with the statutory requirements of bargaining in good faith. See note 36 supra and NLRB v. MacKay Radio \& Telegraph Co., 304 U.S. 333 (1938).

49. See text accompanying notes $45-46$ supra. 
of an extant collective agreement. If the predecessor's employees are indeed to be regarded as employees of the successor, the common law that plays such an important role in defining the duties and rights operative in the relationship should also be applicable. ${ }^{50}$ Third, and more fundamentally, the assumption that a successor cannot justifiably be held to honor the terms of an existing collective agreement springs from the contractual model of collective agreements that was expressly rejected by the Supreme Court in Wiley. ${ }^{51}$ If, as the Court has repeatedly affirmed, the collective agreement is truly a common law of the plant, establishing a system of industrial self-government, ${ }^{52}$ a compelling reason should be required for the unilateral recission of any of the provisions of that common law.

\section{The Chemrock Doctrine Resolved}

\section{a. The Burns Case and the NLRB-Wiley Extended}

This state of affairs was soon altered when the National Labor Relations Board recognized that the Chemrock doctrine was inadequate to effectuate fully the national and employee interests considered so important in Wiley. In 1970, in a series of unfair labor practice cases, the Board achieved theoretical consistency by holding that a "successor" was bound to honor all the terms and conditions of his predecessor's collective bargaining agreement. ${ }^{53}$ In Burns International Detective Agency, Inc., ${ }^{54}$ two companies, Burns and Wackenhut, were in the business of providing plant protection services. Wackenhut's contract with Lockheed was soon to expire. Both companies submitted competitive bids to Lockheed, and Burns' bid was accepted. It chose to retain 27 of the 42 guards who had been employed by Wackenhut and had been represented by the United Plant Guard Workers Union; it also transferred 15 of its own employees to the Lockheed plant. Burns provided the same services as had been supplied by Wackenhut, at the

50. See note 23 supra and accompanying text.

51. See note 19 supra and accompanying text.

52. See, e.g., Wiley \& Sons, Inc. v. Livingston, 376 U.S. 543, 550 (1964); United Steelworkers v. Warrior \& Gulf Navigation Co., 363 U.S. 574, 578-80 (1960).

53. Burns Int'l Detective Agency, Inc., 182 N.L.R.B. 348 (1970); Hackney Iron \& Steel Co., 182 N.L.R.B. 357 (1970); Travelodge Corp., 182 N.L.R.B. 370 (1970) (dictum). In a companion case, where the successor insisted on the union's adherence to the predecessor's contract, the Board held that the union was also bound on the basis of the same policy considerations that supported the Board's conclusion that the successor was bound to honor the previous contract. Kota Div. of Dura Corp., 182 N.L.R.B. 360 (1970).

54. 182 N.L.R.B. 348 (1970). The Board's holding that Burns was bound to honor all of the terms and conditions of his predecessor's collective bargaining agreement was reversed by the Supreme Court. NLRB v. Burns Int'l Security Servs., Inc., 406 U.S. 272 (1972). 
same plant and under identical working conditions. The union demanded that Burns recognize it as the exclusive bargaining agent as well as honor the 3-year collective bargaining agreement, which had been negotiated with Wackenhut only 2 months earlier. Burns refused both demands, and the union brought unfair labor practice charges under section 8(a)(5) of the National Labor Relations Act.

The National Labor Relations Board found Burns to be a "successor" employer by virtue of its "judgment that the employing industry has remained essentially the same despite the change in ownership." ${ }^{55}$ According to the Board, Burns, as the successor, had committed two separate violations of section 8(a)(5): (1) Burns had refused to comply with the union's request for bargaining; and (2) it had refused to honor the contract negotiated with the predecessor even though, by its terms, it would not terminate for more than $2 \frac{1}{2}$ years. ${ }^{56}$ The first violation was based on the line of cases leading up to Chemrock in which successors, having acquired a bargaining unit previously found to be "appropriate," were required to recognize and bargain with the union representing that unit. A related section $8(a)(5)$ violation, based on the Chemrock doctrine, occurred because Burns unilaterally changed terms and conditions, prior to bargaining to impasse, by paying the former Wackenhut guards in Burns' employ less than they had received under the Wackenhut contract. ${ }^{57}$ In addition, the Board held that, by failing to honor the extant agreement, Burns had violated sections 8(d) and $8(a)(5)$ - this finding was based on the principles recognized by the Supreme Court in Wiley. ${ }^{58}$

The Board ordered Burns not only to bargain with the union, but also to make the former Wackenhut guards whole by giving retroactive effect to all clauses of the collective agreement. ${ }^{59}$ Thus, Burns was

55. 182 N.L.R.B. at 349.

56. Id. at $348-49$.

57. See text accompanying note 42 supra.

58. 182 N.L.R.B. at 349-50.

59. The Board's order required Burns to, inter alia:

1. Cease and desist from:

(a) Refusing to bargain collectively, upon request, with the Union . . . .

(b) Refusing to adopt, honor and enforce its contract with the Union, as successor of Wackenhut.

2. Take the following affirmative action . ...

(b) Bargain Collectively, upon request, with the Union and, if any understanding is reached, embody such understanding in a signed agreement.

(c) Honor, adopt and enforce the contract between Respondent, as successor to Wackenhut, and the Union and give retroactive effect to all the clauses of said contract and, with interest of 6 percent, make whole its employees for any losses suffered by reason of Respondent's refusal to honor, adopt, and enforce said contract.

Id. at 355 . 
ordered to pay the guards the difference, with interest, between the rate of pay at which it had compensated them upon its takeover and the rate found in the Wackenhut contract. By finding Burns bound to the agreement in toto (including its remaining 21/2-year term), the Board clearly extended the Chemrock doctrine and, in effect, subsumed the bargaining remedy in the order requiring adherence to the prior contract.

In holding that Burns was bound to abide by all the terms of the contract since it "[stood] in the shoes" Labor Relations Board made a significant extension of Wiley, which it justified as being compelled by the policies underlying that case. ${ }^{61}$ The Board emphasized "[t]he impressive policy considerations favoring the maintenance and adherence to existing collective bargaining agreements," industrial peace being the paramount consideration. ${ }^{62}$ It dismissed any problem under section 8(d) of the National Labor Relations Act, ${ }^{63}$ by reasoning that "a holding that Burns is obligated to honor and adhere to the express terms of the contract [cannot] readily be equated with compelling Burns to agree to a bargaining proposal or make a concession it is unwilling to make." "64 The Board continued: "Indisputably, there is a contract. That contract covers the employees of the employing industry which Burns took over; it was negotiated on behalf of the employing enterprise by Wackenhut, Burns' predecessor." Since the contract was "reasonably related" to Burns through its takeover of the predecessor's entire business operation, the Board con-

60. Id. at 350 . 1971).

61. See Burns Int'1 Detective Agency, Inc. v. NLRB, 441 F.2d 911, 916 (2d Cir.

62. 182 N.L.R.B. at 350.

63. Section $8(d)$, which defines the obligation to bargain collectively as being a mutual obligation on both parties to meet and confer in good faith with respect to wages, hours, and other terms and conditions of employment, establishes a limit on the duty to bargain: "such obligation does not compel either party to agree to a proposal or require the making of a concession." 29 U.S.C. $\$ 158$ (d) (1970).

64. 182 N.L.R.B. at 350 (footnote omitted). In fact, the Board actually gleaned support from section 8 (d) for its position that the successor should be bound by the contract. It noted that the section also defined the duty to bargain as meaning that (in the words of the statute): "where there is in effect a collective-bargaining contract covering employees in an industry affecting commerce . . . no party to such contract shall terminate or modify such contract . . ." 29 U.S.C. \& 158(d) (1970). The section also provides that a party to the contract has the right to refrain from discussing modifications which are to take effect prior to the period fixed by the contract itself for reopening negotiations. From this, the Board concluded that: "Section 8(d) thus clearly demorstrates Congress' recognition of the paramount role in maintaining industrial peace played by parties' adherence to existing collective-bargaining agreements." 182 N.L.R.B. at 350 . Contrast this with the Supreme Court's refusal to enforce the Board's order requiring the successor to honor the terms of his predecessor's collective bargaining contract. See text accompanying notes 73-80 infra.

65. 182 N.L.R.B. at 350. 
cluded that Burns was "bound to that contract as if it were a signatory thereto." ${ }^{66}$

While balancing the interests of successor-employers and employees, the Board in Burns noted that "[The successor] can make whatever adjustments the acceptance of such obligation may dictate in his negotiations concerning the takeover of the business. Normally, employees cannot make a comparable adjustment. Their basic security is the collective-bargaining agreement negotiated on their behalf." ${ }^{67}$ This conclusion was the basis of the Wiley Court's imposition of the duty to arbitrate on the successor. ${ }^{88}$ It represents a point in the evolution of the successorship doctrine at which the need to protect employees in situations where they were powerless to protect themselves predominated over the concern for entrepreneurial freedom for buyers of a business, because the latter could consider the successorship costs in negotiating the purchase of an enterprise.

The Second Circuit Court of Appeals enforced the Board's order "except for that part which requires the company to honor the collective agreement between Wackenhut and its union."69 It was unclear from the opinion whether this exception included the back pay order. If so, the court essentially overruled Chemrock and rejected the theory that a unilateral change in terms and conditions prior to bargaining to impasse constituted a section $8(\mathrm{a})(5)$ violation. ${ }^{70}$ In holding that Burns was not bound to honor the contract, the court of appeals relied on the Supreme Court's 1970 decision in H.K. Porter Co., Inc. v. NLRB, ${ }^{71}$ which held that the Board and the courts are powerless, by virtue of the proscriptions of section $8(\mathrm{~d})$, to compel a company or a union to agree to any substantive provision during the negotiation process. ${ }^{72}$

\section{b. The Burns Case and the Supreme Court-Wiley Retracted}

The Burns case reached the Supreme Court in 1972. ${ }^{73}$ The Court held that Burns was neither bound to honor the union's contract with Wackenhut nor required to make up the pay difference of the former Wackenhut guards. Burns was, however, held subject to a statutory duty to bargain with the previously certified unit representative, which

66. Id.

67. Id.

68. See John Wiley \& Sons, Inc. v. Livingston, 376 U.S. 543, 549 (1964).

69. Burns Int'1 Detective Agency, Inc. v. NLRB, 441 F.2d 911, 914 (2d Cir. 1971).

70. As will be seen, this ambiguity was resolved by the Supreme Court. See text accompanying notes $75-78$ infra.

71. 397 U.S. 99 (1970).

72. For a discussion of the Porter case see text accompanying notes $182-89$ infra.

73. NLRB v. Burns Int'l Security Servs., Inc., 406 U.S. 272 (1972). 
Burns had voluntarily acquired when it selected the employees of the prior employer to perform their old tasks at the former workplace. ${ }^{74}$ Unfortunately, the Court's decision marked both a retraction of the successorship doctrine as developed under Wiley and a rejection of the newly adopted NLRB position that the successor was to be bound by the predecessor's contract.

$i$. Rejecting Chemrock and the NLRB. The Court resolved the ambiguity in the appellate court's opinion concerning the continuing validity of the Chemrock doctrine ${ }^{75}$ by making it clear that the predecessor's employees are not the successor's employees until the successor actually hires them. The consequences of this holding are twofold. First, no duty to bargain matures until such time as it becomes "perfectly clear" that the established union represents a majority of the successor's employees in the bargaining unit. ${ }^{76}$ This is a rejection of the Chemrock holding that the successor automatically assumes a duty to bargain with the predecessor's employees. Second, after the duty to bargain has matured, section $8(a)(5)$ is violated only if the successor, after bargaining for its own agreement with the union, makes a unilateral change in the terms and conditions to which it had previously agreed. The provisions of the predecessor's collective agreement are not to be "imputed to" the successor, as they were in Chemrock, and no section 8(a)(5) violation occurs by virtue of a successor's "unilateral change" in its predecessor's terms and conditions of employment. ${ }^{77}$ Thus, the Court held that although Burns' duty to bargain matured prior to the actual takeover, it did not violate section 8(a)(5) when it paid the former Wackenhut guards less than they had received under the contract with Wackenhut because Burns had not agreed to the higher wage level. The Court stated:

It is difficult to understand how Burns could be said to have changed unilaterally any pre-existing term or condition of employment without bargaining when it had no previous relationship whatsoever [sic] to the bargaining unit and, prior to July 1 [the date of the takeover by Burns], no outstanding terms and conditions of employment from which a change could be inferred. ${ }^{78}$

74. Id. at 278-80.

75. See text accompanying notes $69-70$ supra.

76. 406 U.S. at 294-95.

77. But see, Zim's Foodliner, Inc. v. NLRB, 495 F.2d 1131 (7th Cir. 1974), cert. denied, 419 U.S. 964 (1974). In this case, the Seventh Circuit held, inter alia, that Burns did not preclude finding a section $8(a)(5)$ violation where the successor employer unilaterally changed the provisions of the predecessor's collective agreement after its "voluntary adoption" of those provisions. Voluntary adoption was established in the case by the continuance of the prior terms for a 3-week period subsequent to takeover. Id. at 1143-44.

78. 406 U.S. at 294 (emphasis by the Court). 
Thus, after Burns, the successor's duty to bargain is contingent upon its choice of work force. This gives the successor much more freedom to determine its potential labor law obligations than had been allowed under the Chemrock doctrine.

The most ominous aspect of the Burns case, however, is the rejection of the NLRB's newly adopted view that the successor was bound to honor the predecessor's agreement in toto. Unlike Wiley, the operative policy consideration in Burns was based on section 8(d) of the National Labor Relations Act, which favors private bargaining rather than governmental compulsion for establishing the contractual terms in collective bargaining agreements.

The congressional policy manifest in the Act is to enable the parties to negotiate for any protection either deems appropriate, but to allow the balance of bargaining advantage to be set by economic power realities. Strife is bound to occur if the concessions that must be honored do not correspond to the relative economic strength of the parties. ${ }^{79}$

Thus, consistent with the legislative mandate of section $8(\mathrm{~d})$, industrial peace is to be attained by letting the parties fight it out anew, rather than by allowing employees to retain the protections won under the prior contract. Perhaps, it was argued, the union will do even better the second time around: "[A] union may have made concessions to a small or failing employer that it would be unwilling to make to a large or economically successful firm." ${ }^{80}$ This argument, however, ignores the possibility that without the Chemrock duty to bargain over the continuing employment status of the predecessor's employees, the union could be denied the opportunity to renegotiate terms if the employer fails to hire a majority of its predecessor's employees. Rather than enabling the union and the successor-employer to modify the terms of the prior agreement in a mutually satisfactory manner according to their "relative economic strengths," the Court's decision means that an employer could simply exercise the right to hire a majority of non-union workers and thereby avoid a duty to bargain collectively.

In addition to rejecting the view that the successor was bound to honor the predecessor's agreement in toto, the Court recognized the employers' interest in having freedom to "independently rearrange their businesses." This interest-weighed but not seen as controlling in Wiley - was expressed in Burns in terms of economic impact:

A potential employer may be willing to take over a moribund business only if he can make changes in corporate structure, composition of the labor force, work location, task assignment, and nature of supervision.

79. Id. at 288.

80. Id. 
Saddling such an employer with the terms and conditions of employment contained in the old collective-bargaining contract may make these changes impossible and may discourage and inhibit the transfer of capital. ${ }^{81}$

Apparently, the Court failed to realize that this consideration was present in prior formulations of the successorship doctrine. ${ }^{82}$ Under the prior doctrine, "enterprise continuity" would be lacking in the situation postulated by the Court above, and any order to honor fully the old agreement would be unreasonable since the industrial community it was meant to govern would have substantially changed. Burns had instituted no changes such as those suggested by the Court, however, and it is therefore hard to see how the specter of capital inhibition conjured up by the Court was relevant to the factual situation.

ii. The Attempt to Distinguish Wiley. The Court distinguished Wiley on four grounds. First, the Court noted that Wiley was a section 301 suit in federal court to compel arbitration, ${ }^{83}$ while Burns was an unfair labor practices proceeding in which the provisions of section 8(d) expressly prohibit the National Labor Relations Board from compelling the parties to agree. ${ }^{84}$ This distinction, on the basis of the forum where the action was commenced, contravened the policy favoring uniformity of federal labor law, however, and ultimately the Court admitted that the policies of section $8(d)$ applied equally in both federal court actions and NLRB proceedings. ${ }^{85}$

The second ground for distinguishing Wiley was equally tenuous. The Court stated that the "narrow holding" in Wiley dealt with a "merger occurring against a background of state law" and that it therefore embodied the general rule that in merger situations the surviving corporation is liable for the obligations of the disappearing corporation. ${ }^{86}$ In fact, however, the Wiley Court had expressly refused to rest its result on the New York corporation statute tendered by the union. Rather, it had balanced the interests involved and had reached a result consistent with federal labor policy. The relevance of the form of corporate takeover to the considerations to be balanced in each case is not apparent:

It would derogate from "the federal policy of settling labor disputes by arbitration," United Steelworkers v. Enterprise Wheel and Car Corp., 363 U.S. 593, 596, if a change in the corporate structure or

81. Id. at 287-88.

82. See, e.g., text accompanying notes $25-27$ supra.

83. See note 10 supra.

84. 406 U.S. at 286-87.

85. Howard Johnson Co. v. Detroit Local Joint Exec. Bd., 417 U.S. 249, 255-56 (1974).

86. 406 U.S. at 286. 
ownership of a business enterprise had the automatic consequence of removing a duty to arbitrate previously established; this is so as much in cases like the present, where the contracting employer disappears into another by merger, as in those in which one owner replaces another but the business entity remains the same. ${ }^{87}$

Third, the Court noted that Burns involved a successor's purported duty to abide by every term of the predecessor's collective bargaining agreement, while Wiley involved only the duty to arbitrate. Wiley, the Court reasoned, was a "limited accommodation between the legislative endorsement of freedom of contract [section $8(d)$ ] and the judicial preference for peaceful arbitral settlement of labor disputes . . .."88 This "limited accommodation" did not warrant imposing all conditions of the extant contract on the successor in Burns. ${ }^{89}$ Essentially, the Burns Court saw Wiley as invoking arbitration as an alternate forum for deciding which clauses would survive a takeover ${ }^{90}$ But it should be noted that an arbitration award that imposed the prior contract in toto would probably not be refused enforcement under the judicial standard for review of arbitration awards. ${ }^{91}$ Furthermore, ordering arbitration means that the prior collective bargaining agreement will be at least partially imposed in that the provisions allowing for arbitration are necessarily enforced. Although the Court did not overrule Wileywhich means that the duty to arbitrate presumably exists in the right circumstances $^{92}$-arbitrators, construing the terms of an agreement in light of the prevailing law, will probably adopt restrictive views of what terms survive. Surely, if it contravenes congressional policy for the National Labor Relations Board or the courts to order the successor bound, it must be at least equally as offensive for an arbitrator to do so.

The fourth ground on which Burns was distinguished from Wiley was the existence of several factual differences between the two cases.

87. John Wiley \& Sons, Inc. v. Livingston, 376 U.S. 543, 549 (1964) (emphasis added).

88. 406 U.S. at 286.

89. Id.

90. Arguably, the Court in Wiley felt that the possibilities for a just and equitable accommodation by the arbitrator were sufficient to entrust it to that forum. 376 U.S. at $551-52$ n.5.

91. See United Steelworkers v. Enterprise Wheel \& Car Corp., 363 U.S. 593 (1960); but see Torrington Co. v. Metal Products Workers Union, 362 F.2d 677 (2d Cir. 1966).

92. Nor did the Court overrule Wiley in Howard Johnson. Rather, it implicitly recognized that Wiley possessed some continuing viability in two ways: (1) the Court compared the factual circumstances in the Howard Johnson case with the Wiley standard for successorship liability in order to distinguish the two cases; and (2) it expressly stated that "the protection afforded employee interests in a change of ownership by Wiley" was in each case to be "reconciled" with the new employer's rights. 417 U.S. at 264. See text accompanying notes 132-36 infra. 
Wiley, the Court pointed out, was a merger situation in which the surviving entity took over every tangible and intangible asset and every obligation of the disappearing entity. Burns, on the other hand, involved the replacement through competitive bidding of one service contractor by another-Burns had purchased no assets of any kind from Wackenhut, was liable for none of its financial obligations, and the two had no dealings with each other. ${ }^{93}$ The fact that Burns had hired some of Wackenhut's employees was deemed to be "a wholly insufficient basis for implying either in fact or in law that Burns had agreed or must be held to have agreed to honor Wackenhut's collective-bargaining contract." 94 This distinction between Wiley and Burns seems to have left unanswered the question whether a successor who deals with or purchases assets from its predecessor could be held bound to the latter's collective agreement, in whole or in part. The thrust of the opinion suggests that section 8 (d) precludes such a result. At most, a successor would be subject to a duty to arbitrate. Perhaps, under such circumstances, an arbitrator could justify imposing greater obligations on the successor under the collective agreement than would be possible in a Burns-type case in which the purchase-of-assets factor is missing.

Whatever the obligations of a successor once it has voluntarily hired a majority of its predecessor's employees, as had Burns and Wiley, the Court's dictum in Burns emphasizes that a successor is under no initial duty to hire those employees. In fact, the Burns Court was worried that the successor's right to hire whom it pleased might be infringed upon if it were bound by the terms of the prior agreement:

[T] he successor employer would be circumscribed in exactly the same way as the predecessor under the collective-bargaining contract. It would seemingly follow that employees of the predecessor would be deemed employees of the successor, dischargeable only in accordance with provisions of the contract and subject to the grievance and arbitration provisions thereof. Burns would not have been free to replace Wackenhut's guards with its own except as the contract permitted. ${ }^{95}$

This concern clearly presaged the result in Howard Johnson. ${ }^{96}$

iii. Successorship and the "Transfer of Assets" Test. Justice Rehnquist, writing for four justices, concurred in the Burns Court's holding that the successor could not be held to honor the predecessor's contract, but dissented from the Court's enforcement of the bargaining order on the ground that Burns was not a "successor." In a lengthy

93. 406 U.S. at 286.

94. Id. at 287.

95. Id. at 288 (footnote omitted).

96. See text accompanying notes 135-36 infra. 
opinion, Rehnquist focused at one point on what was meant by the phrase "substantial continuity in the enterprise," the Wiley test of successorship status. He noted that Burns involved only a "naked transfer of employees" between Wackenhut and Burns. ${ }^{97}$ Although "continuity in the enterprise" certainly existed for the former Wackenhut employees hired by Burns, in the sense that they were performing the same tasks at the same location for Burns as they had for Wackenhut, Justice Rehnquist argued that continuity must exist "at least in part on the employer's side of the equation, rather than only on that of the employees."98 Successorship, he asserted, depends on the successor's having succeeded to assets as well as employees:

If we deal with the legitimate expectations of employees that the employer who agreed to the collective-bargaining contract perform it, we can require another employing entity to perform the contract only when he has succeeded to some of the tangible or intangible assets by the use of which the employees might have expected the first employer to have performed his contract with them..$^{99}$

Although the transfer of assets model would provide an administrable rule by which transferees of Burns-type service contracts would be exempted from successorship liability, the model fails to analyze and resolve the conflict among concrete competing interests. The Rehnquist rule of successorship could effectively hinder the development of unionization in areas of industry based on frequently renewed service contracts. Moreover, the notion that obligations concerning labor relations are necessarily linked with asset transfers overlooks the nature of the claims asserted by the employees. Seniority rights, vacation privileges, job security provisions, work assignments and other "claims" the employees might, in the right circumstances, "legitimately expect" the successor to honor are not satisfied out of the physical or intangible assets the successor acquires. Employee expectations are the same whether or not the successor purchases assets. Perhaps the emphasis placed on transfer of assets by the majority ${ }^{100}$ and by Justice Rehnquist reflects a feeling that it is equitable to impose obligations on the successor only when it makes a substantial investment commitment, evidenced by the acquisition of capital assets of the enterprise. Implicit in the distinction is the greater role of wages as a cost factor in laborintensive versus capital-intensive industries. The effect of removing

97. 406 U.S. at 307. See text accompanying notes 93-94 supra.

98. Id. at 305. A similar argument was made by Board Member Leedom in Maintenance, Inc., 148 N.L.R.B. 1299 (1964), when he disagreed with the Board majority's conclusion that a service contractor, like Burns, was under a duty to bargain with its predecessor's employees' union. See note 37 supra and accompanying text.

99. 406 U.S. at 305 (emphasis added).

100. Id. at 286. 
the stabilization afforded by the successorship doctrine across service contract changes is to make employees in the service sector bear the economic burden of inter-employer competition. Especially where the competition is systematized, the possibility for collusion between employers is significant.

iv. Post-Burns Developments: Wiley Revived? Perhaps Burns can be reconciled with Wiley by arguing that the fact situation in Burns did not give rise to a "continuity of enterprise" sufficient to satisfy the Wiley test, since the continuity which did exist was basically on the employee side. ${ }^{101}$ Whether or not this explanation is satisfactory, however, it cannot be denied that although Burns resolves one ambiguity in the successorship doctrine, it raises other, more fundamental questions, including uncertainty regarding the continued validity of Wiley.

In another context, however, the Court has enforced a Board order obligating the "successor" to perform duties its predecessor would have had to perform. In a recent post-Burns case, Golden State Bottling Co. $v . N L R B,{ }^{102}$ a successor had purchased the business and hired its predecessor's employees with knowledge that the predecessor had committed an unfair labor practice under section $8(a)(3)$ of the National Labor Relations Act when it discharged an employee for engaging in union activities. ${ }^{103}$ The Court held that the Board could order the successor to reinstate the employee with back pay. The Court balanced strong employee interests in having a working environment free of the taint of past unfair labor practices against the minimal burden on the bona fide successor if it provides an appropriate remedy to the wrongfully discharged employee and held:

Avoidance of labor strife, prevention of a deterrent effect on the exercise of rights guaranteed employees by section 7 of the Act . . , and protection for the victimized employee-all important policies subserved by the National Labor Relations Act . . .-are achieved at a relatively minimal cost to the bona fide successor. Since the successor must have notice before liability can be imposed, "his potential liability for remedying the unfair labor practices is a matter which can be reflected in the price he pays for the business, or he may secure an indemnity clause in the sales contract which will indemnify him for liability arising from the seller's unfair labor practices." Perma Vinyl Corp., 164 N.L.R.B., at $969 .{ }^{104}$

101. See discussion at note 140 infra.

102. 414 U.S. 168 (1973).

103. Section $8(a)(3)$ states in pertinent part that it is an unfair labor practice for an employer "by discrimination in regard to hire or tenure of employment or any term or condition of employment to encourage or discourage membership in any labor organization . . . " 29 U.S.C. \$ $158($ a )(3) (1970).

104. 414 U.S. at 185. 
In Golden State Bottling, the successor had hired a majority of the predecessor's employees, had acquired "substantial assets" from the predecessor, and had continued the predecessor's business operations "without interruption or substantial change." Under these circumstances, the Court noted, "those employees who have been retained will understandably view their job situations as essentially unaltered."105 Were the successor to fail to remedy the unfair labor practice, these employees might well perceive such a failure "as a continuation of the predecessor's labor policies." ${ }^{106}$ They might undertake collective activity to force remedial action, resulting in labor unrest. And even if they did not, a failure to remedy the wrong might well operate as a deterrent to union activities if the employees identified the successor's labor policies with those of the predecessor. In this sense the successor would stand to benefit from the prior unfair labor practice, particularly if the predecessor's animus toward the union had impelled it to discharge those employees most actively engaged in union affairs, leaving a "leadership vacuum" in the bargaining unit. ${ }^{107}$

The Court cited Wiley for the proposition that the objectives of the National Labor Relations Act mandated some protection for employees from sudden changes in the employment relationship. ${ }^{108}$ Here, the change in ownership left the victimized employee (and the others in the bargaining unit) without an effective remedy against the predecessor. If the successor were also immune from having to take remedial action, the violation would go uncorrected. The Court reiterated, however, that the policy of employee protection is not without limits, noting that it cannot be extended so far as to justify requiring a successor to abide by the terms of its predecessor's contract, in light of the section 8(d) policy against compelling a party to agree to substantive contractual obligations. In the instant case, however, since no congressional policy existed against imposing liability upon the successor for its predecessor's unfair labor practice, and since it was not unduly onerous to do so, the Court held that employee interests should be granted protection. ${ }^{109}$

\section{The Development of the Successorship Doctrine: Summary}

The opinions in these three major successorship cases-Wiley, Burns and Golden State Bottling-manifest the Court's willingness to weigh competing interests in formulating rules governing successorship liability once the successor has voluntarily hired some or most of his

105. Id. at 184 .

106. Id.

107. Id. at 184-85.

108. Id. at 182 .

109. Id. at $\mathbf{1 8 5}$. 
predecessor's employees. But, as the Court indicated by way of dictum in Burns ${ }^{110}$ and in Golden State Bottling, ${ }^{111}$ and as it later held in Howard Johnson, there will be no weighing of interests concerning the successor's right not to hire those employees in the first instance. Such employee protection policies as are found in the National Labor Relations Act extend only to those employees who, in the untrammeled discretion of the successor, are fortunate enough to be retained in their previous jobs. As a practical matter, the efficacy of the successorship doctrine to protect the employee interests recognized in Wiley is compromised by this employer "right" to unlimited discretion in hiring.

\section{II}

\section{THE Howard Johnson CASE: the Supreme Court Plays the Numbers Game}

\section{A. The Facts and the Holding}

The facts of the Howard Johnson case are simple. The Howard Johnson Company, a national restaurant and motel chain, bought out one of its franchise owners, the Grissom family, who had operated a Howard Johnson's Motor Lodge and an adjacent Howard Johnson's Restaurant in Belleville, Michigan. All personal property of the franchise was transferred to the Company. The Grissoms retained ownership of the real property only, which they leased to Howard Johnson. There was no hiatus in the operation of the business and the Howard Johnson Company provided substantially the same products and services at the same location and under the same trade name as had the Grissoms.

The takeover by Howard Johnson was a paradigm of "continuity of the business enterprise," with one exception: Howard Johnson retained only nine of the Grissoms' 53 employees. Although Howard Johnson was on notice that a collective bargaining agreement existed, the company made it clear during the sale negotiations that it intended to operate the business with a substantially different work force. ${ }^{112}$ The Grissom employees had been given notice that at the time of the actual takeover their employment would be terminated.

The Grissoms' employees were represented by the Hotel and Restaurant Employees and Bartenders International Union. After learning that Howard Johnson had retained but a small fraction of the former employees, the union invoked the courts to protect the jobs of the

110. See 406 U.S. at 280 n.5.

111. See 414 U.S. at 184 n.6.

112. Detroit Local Joint Exec. Bd. v. Howard Johnson Co., 482 F.2d 489, 491 (6th Cir. 1973). 
terminated workers. It filed an action in state court, requesting a preliminary injunction against Howard Johnson's actions-actions which, if taken by the Grissoms, would clearly have violated the union's collective bargaining agreement with the Grissoms. ${ }^{113}$ The union also sought an order compelling Howard Johnson and the Grissoms to arbitrate the extent of their obligations to the former employees under the bargaining agreement. After the state court granted an ex parte temporary restraining order, which Howard Johnson failed to honor, the action was removed to federal court. The Grissoms conceded their duty to arbitrate, and the federal district court held that Howard Johnson was also required to arbitrate the extent of its obligations to the former Grissom employees. ${ }^{114}$ The request for an injunction requiring the company to hire the former employees was, however, denied. ${ }^{115}$ Howard Johnson appealed the arbitration order to the Sixth Circuit Court of Appeals, which, affirming on the basis of Wiley, concluded that Wiley was more on point than was Burns. ${ }^{116}$

Addressing the issue of Howard Johnson's duty to arbitrate, the court of appeals used a two-tier analysis, first asking whether the company was a successor employer, then determining whether a successor is bound to arbitrate its obligations under an extant collective agreement. The court used the "substantial continuity" test to determine whether Howard Johnson was a successor. In evaluating the degree of continuity, the court followed the Supreme Court's decision on Burns and considered various characteristics of the business before and after the transfer. ${ }^{117}$ Among the characteristics considered were the

113. There were actually two separate collective bargaining agreements at issue in the litigation, each covering the employees at different establishments. Both agreements contained arbitration provisions as well as clauses stating that the agreements would be binding on the employer's "successors, assigns, purchasers, lessees or transferees." Howard Johnson Co. v. Detroit Local Joint Exec. Bd., 417 U.S. 249, 251 (1974). Thus, for present purposes these agreements can be treated as identical.

114. Detroit Local Joint Exec. Bd. v. Howard Johnson Co., 81 L.R.R.M. 2329 (E.D. Mich. 1972).

115. The district court gave the following reasons for its denial of injunctive relief: (1) irremediable financial harm would result to the new employees hired by Howard Johnson, whereas under the court's arbitration order, the terminated employees had available to them the possibility of restitution and reimbursement, depending on the arbitrator's decision; (2) arbitration would not be a lengthy process and, in the meantime, there should be an attempt to avoid disruptive changes; (3) the requirement that injunctive relief be granted only upon plaintiff's showing of probable success on the merits was not satisfied since, given the conflict between Burns and Wiley, the "situation [was] not well enough developed for the Court to prognosticate" success on the merits. Id. at 2335 .

116. Detroit Local Joint Exec. Bd. v. Howard Johnson Co., 482 F.2d 489 (6th Cir. 1973). For a discussion of Wiley and Burns, see Part I supra.

117. 482 F.2d at $492-93$. 
prior and subsequent structure of the business operation, ${ }^{118}$ the location of the operation, ${ }^{119}$ the nature of the work, and the identity of the employees. ${ }^{120}$ The court, treating the lack of continuity in the work force as one factor in the equation, found substantial continuity in the operation of the enterprise. ${ }^{121}$ Finding the employer to be a "successor," the court went on to the second question and held that, under Wiley, Howard Johnson was bound to arbitrate. ${ }^{122}$

Howard Johnson's argument that the absence of continuity in the work force should be dispositive of the issue of successorship, was characterized as an "attempt to pull itself up by its own bootstraps."123 If the policies underlying the successorship doctrine are to have any force, the party purchasing a business cannot be permitted unilaterally to determine its legal status:

[T]o adopt the position urged by Howard Johnson would make the employees' jobs completely contingent on the employer's desire either to retain or to disregard the collective bargaining agreements. If Howard Johnson sought to retain the agreement negotiated by Grissoms, it would hire a majority of Grissoms' employees. If, on the other hand, it wished to disregard the collective bargaining agreement, it would simply hire none or at best only a few of the former employees. The decision whether to hire the predecessor's employees should turn upon other and more relevant considerations. ${ }^{124}$

The company urged, however, that even if "substantial continuity" is found in this fact situation, the arbitration remedy sought should be foreclosed by Burns since the duty to arbitrate is a substantive contractual term. The court of appeals rejected this argument, however, and found Burns inapposite, relying on two of the grounds used by the Supreme Court in that case to distinguish Wiley: (1) in the instant case the union had brought a section 301 suit for breach of the collective agreementthus, the issue of the limitation of the Board's remedial powers, under section 8(d) which had been recognized in the Burns case, was not present; ${ }^{125}$ and (2) the remedy being sought by the union in Howard Johnson was arbitration, whereas in Burns the petitioner had sought to impose the complete range of obligations contained in the collective

118. NLRB v. Zayre Corp., 424 F.2d 1159, 1163 (5th Cir. 1970); S.S. Kresge Co. v. NLRB, 416 F.2d 1225 (6th Cir. 1969).

119. NLRB v. Zayre Corp., 424 P.2d 1159 (5th Cir. 1970); S.S. Kresge Co. v. NLRB, 416 F.2d 1225 (6th Cir. 1969).

120. See, e.g., NLRB v. Zayre Corp., 424 F.2d 1159 (5th Cir. 1970); Tom-A-Hawk Transit, Inc. v. NLRB, 419 F.2d 1025 (7th Cir. 1969).

121. 482 F.2d at 493.

122. Id. at 495 .

123. Id.

124. Id. at 493-94.

125. Id. at 495. 
agreement. ${ }^{128}$ The court reasoned that to read Burns as the company urged-foreclosing the arbitration remedy in suits against successorswould effectively overrule Wiley, something the Burns Court had declined to do. ${ }^{127}$

Howard Johnson's petition for a writ of certiorari was granted, and the Supreme Court reversed. ${ }^{128}$ The Court first considered the forum distinction that had been found significant in Burns. It retreated from the idea that the distinctions between a section 301 suit and an unfair labor practice proceeding justify granting in one forum a remedy that might have been unavailable in another forum. ${ }^{128}$ The Court reasoned that guidance for the federal common law, which federal courts were authorized to develop under section 301, was to be found not only in the express terms of the National Labor Relations Act, but also in the policies underlying the national labor laws. ${ }^{130}$ Having earlier recognized in Burns that the policies of section 8(d) of the National Labor Relations Act are controlling in an unfair labor practice proceeding involving an issue of successorship, the Court concluded that those policies should also control in section 301 actions; a contrary holding would permit the employer's rights in a successorship situation to depend on the union's choice of forum. The Court observed that "[c]learly the reasoning of Burns must be taken into account here."131

Recognizing that the policies underlying Wiley and Burns are somewhat inconsistent, especially if the latter decision is read broadly, the Court stated that it was unnecessary to decide whether the conflict was irreconcilable. ${ }^{132}$ Rather, the Court distinguished Wiley on at least three grounds. First, the merger in Wiley had been conducted against a background of state corporation law holding the surviving entity liable on the contracts of the disappearing corporation. Consequently, the successor could reasonably have expected to be held to arbitrate under the predecessor's contract. Second, the predecessor employer in Wiley had ceased to exist as a legal entity. Thus, unless the union had some recourse against the successor, it would have had no means of enforcing the obligations voluntarily undertaken by the merged corporation. In Howard Johnson, however, the Grissom corporations continued to exist as viable entities with substantial assets, out of which the union's contractual claims could be satistifed. ${ }^{133}$ Finally, and most

126. Id.

127. Id.

128. Howard Johnson Co. v. Detroit Local Joint Exec. Bd., 417 U.S. 249 (1974).

129. Id. at 255 .

130. Id. at $255-56$.

131. Id. at 256.

132. Id.

133. Id. at 257. In this connection, the Court noted that the Grissoms had al- 
significantly, the Court found that the substantial continuity test outlined in Wiley was not satisfied in Howard Johnson since a majority of the Grissoms' employees had not been hired by Howard Johnson: "[C]ontinuity of identity in the business enterprise necessarily includes, we think, a substantial continuity in the identity of the work force across the change in ownership." ${ }^{34}$ In discussing this element of the case, the Court addressed the core of the union's position, which was that the request for arbitration was motivated by the union's desire to assert rights to employment on behalf of those not hired by Howard Johnson. ${ }^{135}$ By rejecting the union's position, the court gutted the policy of employee protection in the successorship context and left no doubt that employees of a predecessor have no legal right to continued employment with a new employer: "This holding is compelled, in our view, if the protection afforded employee interests in a change of ownership by Wiley is to be reconciled with the new employer's right to operate the enterprise with his own independent labor force."136

\section{B. Analysis and Criticism}

\section{Howard Johnson and the Successorship Doctrine}

Part I of this Comment examined the history of the "substantial continuity" in the employing enterprise test and outlined the contours and underlying policies of the successorship doctrine. The following discussion will suggest that the Howard Johnson Court severely eroded the successorship doctrine and compromised the interests of employees by holding that the absence of a single factor relevant to determining successorship - continuity of the work force-necessarily means that "substantial continuity" does not exist across a change of ownership.

\section{a. "Interest Analysis" of Successorship: \\ Tipping the Scales in Favor of Employers}

In reaching its holding, the Court refined the appropriate test for determining whether obligations should be imposed on successor-employers, noting that "[t]he question whether Howard Johnson is a 'successor' is simply not meaningful in the abstract."137 The majority took issue with the "artificial division" in the two-tier analysis used by the court of appeals, according to which the successorship issue was resolved before the question whether there was a duty to arbitrate was

ready agreed to arbitrate the extent of their liability to the union and their former employees. Id. at 257-58.

134. Id. at 263.

135. Id. at 260-61 nn. $6 \& 7$.

136. Id. at 264 .

137. Id. at 262-63 n.9. 
reached. ${ }^{138}$ The Supreme Court found this two-tiered model analytically unsound and adopted instead an approach inextricably linking the determination of successor status to the obligation sought to be imposed.

[T]he real question . . . is . . . what are the legal obligations of the new employer to the employees of the former owner or their representative. The answer to this inquiry requires analysis of the interests of the new employer and the employees and of the policies of the labor laws in light of the facts of each case and the particular legal obligation which is at issue, whether it be the duty to recognize and bargain with the union, the duty to remedy unfair labor practices, the duty to arbitrate, etc. There is, and can be, no single definition of "successor" which is applicable in every legal context. A new employer, in other words, may be a successor for some purposes and not for others. ${ }^{139}$

The Court rightly recognized that the tailoring of legal obligations to the relevant national and individual interests inevitably at issue when a business changes hands is a superior approach in view of the "delicate balance" underlying the National Labor Relations Act. ${ }^{140}$

138. Id. See text accompanying notes 117-22 supra.

139. 417 U.S. at 262-63 n.9.

140. See also NLRB v. Fruit \& Vegetable Packers Union, 377 U.S. 58 (1964).

In successorship situations, the employees' interests usually concern job or benefit protection under the contract their union has negotiated with the predecessor, or protection from a working environment tainted by past unfair labor practices. The successor's interest concerns the freedom to determine its own obligations and to commence operations in its new enterprise free of whatever duties or obligations its predecessor might have undertaken or been subject to. It is the task of federal labor law to strike a balance between these obviously competing interests.

Given that the relevant interests and policies remain substantially the same in any situation involving the change of ownership of an employing enterprise, the precise factual circumstances determine liability. Perhaps the Court's newly enunciated successorship methodology suggests that, in light of the national interest in business stability, a greater quantum of "continuity in the enterprise" is required in order to justify holding a successor to a potentially more onerous obligation-such as the duty to arbitratethan is required to hold it to a lesser obligation-such as the duty to bargain. If this is a correct interpretation of the Court's interest analysis methodology, perhaps a reconciliation between Wiley and Burns can be fashioned after all, if it is assumed that Burns left open the question of a successor's duty to honor its predecessor's contract. In Wiley, the extent of enterprise "continuity," or "continuity index," was great, from both the successor's and the employees' standpoint, and the obligation sought to be imposedthe duty to arbitrate-was not severely onerous. In Burns, on the other hand, the "continuity index" was significantly lower (especially in light of the fact, as pointed out by Justice Rehnquist, that continuity did not exist at all from the successor's standpoint), whereas the obligation sought to be imposed-the duty to abide by the substantive terms of the predecessor's contract in toto-was substantially more onerous than that sought to be imposed in Wiley. Under this analysis, Golden State Bottling is clearly closer to Wiley than it is to Burns, since the "continuity index" was high and the burden sought to be imposed on the successor was minimal.

For detailed descriptions and analyses of Wiley, Burns and Golden State Bottling, see Part I supra. 
Nothing in the above-quoted passage, however, limits the application of this "interest analysis" methodology to those situations in which the successor has actually decided to hire the predecessor's employees. On the contrary, analytical consistency demands that all legal obligations of the new employer, including the duty to retain the predecessor's employees, be considered in light of all relevant interests. Moreover, given that the successorship doctrine itself was formulated for the purpose of providing legal protection to employee interests, ${ }^{141}$ enabling a successor to determine for itself whether it is to be obligated to continue the established common law, by simply deciding whom to hire, abrogates the doctrine and compromises the underlying national interests and policies.

Indeed, it is not clear that the court even applied the balancing test it described to the facts of Howard Johnson. At best, the Court's manner of applying the interest analysis to the duty to hire issue in Howard Johnson was remarkably absolutist considering its requirement that the competing interests be analyzed in light of the particular obligation at issue. Rather than apply the balancing test enunciated in its opinion, the Court simply focused on the new employer's interest in hiring discretion. ${ }^{142}$ Both the employee interest in continued employment and the national interest in industrial peace were given short shrift. Unless these interests were implicitly thought to be de minimis, the result in Howard Johnson should have been reached only after full consideration of the various interests and of alternative modes for sustaining them. The Court should have undertaken the same careful weighing of employee-employer interests in Howard Johnson that it employed in Golden State Bottling. ${ }^{143}$ The successor's interest in restructuring the work force should not be treated as absolute-but this is the probable result of the rule, adopted by the Court in Howard Johnson, that "successorship" will not be found if substantial continuity in the work force is absent.

The Court seemed to justify the deference to employer prerogatives by quoting its earlier opinion in Burns, which gave controlling weight to the fact that "[a] potential employer may be willing to take over a moribund business only if he can make changes in corporate structure,

141. See text accompanying notes $12,21-22$ supra.

142. The Court briefly discussed the policy of "affording protection to those employees who are in fact retained . . ." 417 U.S. at 264.

143. Golden State Bottling Co. v. NLRB, 414 U.S. 168, 181-85 (1973). In that case, the powerful employee interests in a working environment free of the taint of past unfair labor practices were balanced against the burden imposed on the successor when it is required to reinstate a wrongfully discharged employee. For a more extensive discussion of the case, see text accompanying notes 102-09 supra. 
composition of the work force, . . . and nature of supervision."144 In addition to the concerns adopted from the Burns opinion, Howard Johnson reflects an implicit concern for the potential economic impact of imposing a predecessor's obligations to its employees upon the successor. ${ }^{145}$ Although these management interests may have been sufficient to conclude that Howard Johnson need not have assumed the Grissoms' collective bargaining agreement, these will not always be the only interests to be seriously considered, as the Howard Johnson rule itself would suggest. If anything, other relevant interests, such as the interest of employees in continued employment and the interest of the public in industrial peace, should be given greater weight and should not be compromised to the degree that they were in Howard Johnson.

Indeed, it is not clear what the Court hoped to accomplish by applying its balancing test as it did. In recognition of the fact that a new employer has a significant interest in making changes in the structure of the business, the traditional test of "enterprise continuity" allowed courts to take into account the technological and structural transformation, which often accompanies a change of ownership, before imposing a duty to arbitrate or bargain. ${ }^{148}$ Similarly, the decisions of arbitrators regarding the contractual obligations of a successor have been sensitive to the problems involved in these "changes in corporate structure."147 The Court's treatment of employer-employee interests in Howard Johnson did more than perpetuate the judicial-arbitral deference to successor interests; it forced an overemphasis on successor desires and destroyed the balance ostensibly favored by the test announced by the Court in the same case.

The second interest mentioned by the Court-the interest of a successor employer in controlling the composition of its work forcecould be adequately protected without completely disregarding the interests of the employee unit. An employer has a valid interest in employing suitable workers. When a business is transferred, a successor employer might justifiably believe that the predecessor's work force was unsatisfactory. If the successor-employer claims that certain of the predecessor's employees are unacceptable, a resolution of the problem could be achieved either through union-employer discussions or by submitting the issue to arbitration. The successor would be required to provide a reasonable justification for its refusal to hire particular employees so as to prevent the successor from masking anti-union motives

144. 417 U.S. at 261 , citing 406 U.S. at $287-88$.

145. 417 U.S. at 255.

146. Compare John Wiley \& Sons v. Livingston, 376 U.S. 543 (1964), with NLRB v. Alamo-White Truck Serv., Inc., 273 F.2d 238, 240 (5th Cir. 1959).

147. See Interscience Encyclopedia, Inc., 55 Lab. Arb. 210 (1970) (Roberts, Arbitrator). 
under a broad hiring discretion. ${ }^{148}$ Moreover, the successor would retain the rights of the predecessor under the contract, including the right to discharge employees for cause. Such a termination for cause procedure would undoubtedly be more burdensome for an employer than would be the unfettered right to fire an employee without providing any justification, but necessary changes in the composition of the work force would not be totally precluded. Similarly, it would be true that where the successor encountered overstaffing, layoffs would be proper, as long as the layoff priorities established by the extant agreement were honored.

The last-articulated employer interest in Howard Johnson-the right to control the nature of supervision in the enterprise,-involves treatment of both the framework of rules governing work procedures and the supervisory personnel who implement those rules. The problem of supervisory personnel poses the least trouble due to the special provisions of the National Labor Relations Act exempting supervisors from "employee" status and providing that employers need not consider supervisors as employees under any law relating to collective bargaining. ${ }^{149}$ Given this special statutory treatment and the fact that any collective agreement with supervisors concerning the terms and conditions of their employment is utterly voluntary, a strong argument can be made that a special rule should apply to supervisors. ${ }^{150}$ With regard to the rules governing work procedures, the role of the arbitrator should be very significant. The arbitrator would examine the successor's proposed changes in both the work environment and in the division of labor and then determine what work rules should survive the ownership transition. Although the use of the arbitration procedure will prevent the employer from unilaterally imposing new regulations, the compromise reached will recognize the successor's interests. ${ }^{151}$

148. Under the Howard Johnson rule and the recent section 8(a)(3) violation cases (see notes 205-26 and accompanying text infra) a sophisticated employer can be motivated by anti-union attitudes and still avoid liability. More broadly, however, where the burdens on the employer under the collective agreement can be minimized, the refusal to hire the predecessor's employees can arguably be seen as based on an antiunion attitude. The absence of alternative justifications should raise an inference of union animus, even in the absence of specific evidence.

149. 29 U.S.C. $\S \S 152,164$ (1970).

150. It could be persuasively argued that an employer has a greater interest in controlling its supervisory personnel than it has in controlling its rank and file personnel. Also, the criteria of acceptable performance at the managerial level tend to be more subjective than are the performance standards for rank and file employees. The customary patterns of American labor relations have certainly molded the expectations of the parties in this area, and a special rule here seems to be more consistent with relevant expectations and interests than is the more general rule of Howard Johnson.

151. The arbitration procedure has long been recognized by the courts as well suited for achieving fair and equitable results. See, e.g., United Steelworkers v. Reliance Universal Inc., 335 F.2d 891 (3d Cir. 1964). 
Consideration should also be given to the economic impact of imposing on a successor the predecessor's contractual duties, since this is arguably a major factor in an employer's refusal to honor the prior employer's obligation. The successor could, of course, protect itself by adjusting the purchase price, as the Golden State Bottling Court suggested. ${ }^{152}$ Admittedly, the valuation problem may be difficult, but it is by no means insurmountable. Similarly, the contract of sale could include an indemnification agreement whereby the predecessor assumed specified liabilities arising from the imposition of the extant collective agreement. The purchaser might also time its acquisition to coincide with the termination of the predecessor's collective bargaining agreement and negotiate acceptable terms at that point. One problem with this suggestion, however, is the possibility that the flow of capital would be restricted because, given market fluctuations, there is no guarantee that the end of the contract would coincide with the optimum time to buy. The weight of this factor is questionable, however, given that data on merger and acquisition are at best inconclusive on the question what effect requiring successors to honor extant collective agreements has had on the free flow of capital. ${ }^{153}$

\section{b. Other Factors}

If the preceding analysis of the Court's treatment of the successor's interests casts doubt on the wisdom of the result in Howard Johnson, consideration of other relevant factors adds to that doubt. The public

152. 414 U.S. at 185. In Golden State Bottling, the predecessor had committed an unfair labor practice. Since the successor had notice of this situation, it was bound to remedy the wrong committed. A price could have been ascertained because the remedy involved making the former employee whole with back pay. See text accompanying notes 102-09 supra. In situations such as the one in Howard Johnson, however, the price is necessarily more subjective.

153. One might, for example, expect that one impact of Wiley's imposition of the obligation to arbitrate under the prior collective agreement on the successor would have been to retard the total number of mergers and acquisitions. In fact, in the 4 years prior to 1964 (the year Wiley was decided), the average yearly increase in total mergers and acquisitions in the United States was only 0.5 percent, as compared with 25.6 percent over the 5-year period thereafter. U.S. Bureau of the Census, Statistical ABSTRACT OF THE UNITED STATES 474 (1971). Concededly, the number of mergers and acquisitions that occur in a given year is a function of many variables and these statistics do not rebut the argument that, had it not been for Wiley, the increase thereafter would have been even more dramatic. Nevertheless, the negative conclusion can be drawn that no obvious correlation exists between the imposition of successorship liability and the merger and acquisition rate.

Thus, at the very least, it can be said that the exact magnitude of the restriction of capital flow and the attendant debilitating effect on the market are highly conjectural and may in fact be minimal, whereas the adverse impact on individual employees displaced by changes in ownership is certain and substantial. In weighing these competing interests, doubts should be called in favor of the impact which is certain; that is, in favor of the interests of employees. 
interests in collective bargaining and peaceful resolution of labor disputes, for example, are compromised by the Howard Johnson rule allowing successor employers unilaterally to determine their labor obligations. Given that every contract asserted in the successorship context is the result of the representation and bargaining processes contemplated by the National Labor Relations Act, to allow them to be abrogated in cases where employer interests are far from compelling is to derogate the efforts that gave rise to the agreement and arguably discourage organizing in certain employment situations. ${ }^{154}$ Absent substantial alteration of the enterprise, the negotiated and often painfully derived "common law of the shop" remains a viable set of regulations to govern the operation of the system, and this common law should not be ignored without compelling justification. ${ }^{185}$

The most glaring defect in Howard Johnson, however, is the Court's failure to recognize the employees' interest in continued employment. When a collective agreement provides for continued employment for a definite term, a termination of employment simply because the ownership of the enterprise changes hands violates deeply felt expectations of the employees. The Supreme Court rightly concluded that, before any obligation can be imposed upon a successor, substantial continuity must be found with respect to that specific obligation. But the Court erred by not applying this test to determine whether the successor should be required to retain the former employees. Instead, the Court stated that there was no such duty, giving only lip service to employee interests, including employee interest in employment.

\section{The Concept of Employment as a Property Right Worthy of Judicial Protection}

In analyzing the interests involved in Howard Johnson, the Supreme Court concluded that the successor's desire to operate with an independent work force should predominate over the interests of the predecessor's employees in retaining their jobs. Given recent developments in labor law and in analogous areas of law, the holding seems to be a retreat from emerging notions of "property" rights. ${ }^{156}$ The idea

154. Once employees note the operation of the rule in Howard Johnson and the ability of the employers unilaterally to terminate an extant collective agreement, they will, at least arguably, be chilled in the exercise of their section 7 rights. See notes 190-94 infra and accompanying text.

155. Cf. Wackenhut Corp. v. Plant Guard Workers Int'l Union, 332 F.2d 954 (9th Cir. 1964) and United Steelworkers v. Reliance Universal Inc., 335 F.2d 891 (3d Cir. 1964).

156. Many of the ideas and sources for the arguments that follow are taken from McClintock, Enterprise Labor and the Developing Law of Employee Job Rights, 8 GonZAGA L. Rev. 40 (1972) [hereinafter cited as McClintock]. 
that employees have a proprietary interest in their jobs is rooted in a modern conception of the collective agreement ${ }^{157}$ and in a social attitude that views the employment relationship like property. ${ }^{158}$ In the context of successorship, this modern view of employment would mean that in cases where the traditional test of substantial continuity was satisifed, the employees' proprietary interest in employment would continue to exist and could be enforced through the collective agreement.

Commentators have recently recognized the appropriateness of providing legal protection for the employees' interest in continued employment. $^{159}$ On a psychological level, the expectation of continued employment is taken as a given for wage earners. Mature industrial societies tend to support and encourage feelings of "job ownership."160 Legally, however, the interest has been recognized only if it exists in conjunction with a contractual clause embodying a substantive right. Indeed, given that the statutory structure of labor relations in the United States revolves around collective bargaining procedures, it is only in the negotiated agreement that substantive employment rights can be said to reside. ${ }^{161}$

As noted earlier, the Court has recognized the special functions of the collective agreement and the fact that it countenances more than traditional contract-type obligations and rights. ${ }^{162}$ The agreement has been characterized as "an effort to erect a system of industrial selfgovernment,"163 and as a "trade agreement"164 to govern the terms and conditions of the total employment relationship. "It at heart is an instrument of governance- of law." ${ }^{165}$ As opposed to contract formation generally, the pre-agreement negotiation process is initiated and regulated by statute and is more compulsory than it is voluntary. Similarly, while the reinstatement order is a commonplace remedy for a wrongfully discharged employee, specific performance remains the exception rather than the rule in contract law. Thus, any analysis of the legal effects of the collective bargaining agreement should be based on an appreciation of its peculiar nature and functions rather than on contract law.

157. See John Wiley \& Sons, Inc. v. Livingston, 376 U.S. 543, 548, 550-51 (1964), and text accompanying notes 16-27 supra.

158. See F. Meyers, OWNership of Jobs: A Comparative Study (1964) thereinafter cited as MEYERS].

159. See McClintock, supra note 156 , and sources noted therein.

160. See MEYERS, supra note 158 , at 112.

161. Ford Motor Co. v. Huffman, 345 U.S. 330, $331-34$ (1953).

162. See note 19 supra and accompanying text.

163. United Steelworkers v. Warrior \& Gulf Navigation Co., 363 U.S. 574, 580 (1960).

164. J.I. Case Co. v. NLRB, 321 U.S. 332, 335 (1944).

165. McClintock, supra note 156 , at 55. 
The collective agreement is the instrument through which the constitutents in the industrial enterprise reach a viable understanding of one another's duties and rights. The nature of the interests of the constituents has been vividly portrayed by Dean Leon Green in his description of the "industrial enterprise":

The industrial enterprise is not made up merely of land, brick, mortar and machinery on the one hand, and personal services of many individuals on the other. These two great interests of property and personality are both essential to the enterprise, but each alone is meaningless to the industrial world. It is their joinder that creates the third great interest, the industrial relation upon which industry is based. . . . The contributions of those who make up the corporate organization on the one hand are visualized in plant, machinery, raw materials and the like. They can be seen, recorded and valued in dollars. We call them property. On the other side are hundreds of personalities who have spent years training their hands and senses to specialized skills; who have set up habitations conveniently located to their work; who have become obligated to families and for the facilities necessary for maintaining them; who have ordered their lives and developed disciplines; all to the end that the properties essential to industry may be operated for the profit of the owner group and for their own livelihoods. Their outlays are not so visible, nor so easily measured in dollars, but in gross they may equal or even exceed the contributions of the other group. Both groups are joint adventurers, as it were, in industrial enterprise. Both have and necessarily have a voice in the matters of common concern. Both must have protection adequate to their interests as against the world at large as well as against the undue demands of each other. ${ }^{166}$

Dean Green remarks that this joint enterprise gives rise to reciprocal rights and obligations between employers and employees, and that the unilateral right to discharge an employee "has no place in a relation which is based upon infinitely more than a mere contract." ${ }^{167}$

The collective agreement is the vehicle by which the interests of the enterprise's constituents are given legal status. The major foci of collective bargaining agreements are employee job rights and security, and the growth and persistence of trade unionism and collective bargaining are strongly linked to employees' desires and needs for job tenure and security. ${ }^{168}$ Most collective agreements contain provisions for seniority

166. Green, The Case for the Sit-Down Strike, The New Republic, March 24, 1937 , at 199.

167. Id. at 200.

168. L. Reynolds, Labor Economics and Labor Relations 497-518 (6th ed. 1974). 
rights and permit discharge or discipline only upon "just cause."169 Seniority rights reflect the notion that the longer one works at a job the greater "stake" or "interest" he or she has in the enterprise. This interest is vindicated through the common practice of granting tenured employees preference in bidding for new positions and providing them with protection in slack times when layoffs are required. Likewise, the prevalence in collective bargaining agreements of restrictions on disciplinary measures, such as the "just cause" requirement, indicates the sensitivity of employees and their unions to the need for mechanisms to protect the employees' reasonable expectation of continued employment. ${ }^{170}$

The implied duties generated by the collective agreement are like a system of law, negotiated by the parties to regulate their conduct in the industrial context. This analogy to the idea of government has been relied on to escape a narrowly contract-oriented judicial interpretation of the collective agreement. ${ }^{171}$ The terms of the agreement are binding on all employees in the bargaining unit, even though they might individually be able to negotiate more favorable terms. ${ }^{172}$ Furthermore, its terms are binding on employees who enter the unit after the agreement is executed, even if turnover in the unit affects more than a majority. ${ }^{173}$

Since the "common law" obligations and rights of a collective agreement reach beyond the contracting parties, it is difficult to find a convincing justification for not binding the class of employers unless objective changes have caused the agreement to be totally inapplicable to the governance of the enterprise. Recognition of the interests of the two

169. Eighty-nine percent of all collective bargaining agreements place some limitations on the right to discharge, generally through a "just cause" provision. Collective Bargaining Negotiations \& Contracts $\$ \$ 40: 1,40: 11$ (BNA 1975).

170. See generally McClintock, supra note 156, at 58-59. Professor McClintock presents a cogent argument for extending the right of the employee not to be discharged beyond contractual "just cause" provisions. His argument, based both on the relation between the collective bargaining agreement and the National Labor Relations Act and on the employer's right to discharge an employee for "cause" (section 10(c) of the National Labor Relations Act, 29 U.S.C. $\$ 160$ (c) (1970)) is that

[a]n employer breach of the terms and conditions contained in the collective agreement-the common law of the shop-is tantamount to abridging employee rights. An "unjust discharge"-one without cause-could properly be viewed as an interference, restraint, or coercion of an employee's section 9(a) rights guaranteed by section 7 of the Labor Act-i.e., an employer 8 (a) (1) unfair labor practice.

McClintock, supra note 156, at 63 . Courts, however, have yet to adopt this line of reasoning. Present law is that an employer may discharge an employee for any reason if the discharge is not inconsistent with the contract and is not motivated by the employee's union activity. See id. at 60-64.

171. P. Selznick, Law, Society, and Industrial Justice 153 (1969).

172. J.I. Case Co. v. NLRB, 321 U.S. 332, 338 (1944).

173. See General Cable Corp., 139 N.L.R.B. 1123 (1962). 
groups should be parallel, and all the parties entering the enterprise should be required to accede to the terms of the "common law," unless it is demonstrated that the nature of the entity has been transformed. As an AFL-CIO brief suggested, it is "[n]o more radical to hold that a purchase of a business is bound by the agreement than it is to hold that subsequently hired employees are bound by it. Both are strangers to the agreement when made. But both should be held to accept the agreement as the rule of the community as a condition of their entrance into it."174

If the peculiar nature of collective agreements demands that there be no unilateral abrogation of their terms except when an agreement is no longer reasonably related to the enterprise in question, under what circumstances should that protection be granted and what form should it take? The most expansive extension of the argument that employees have property rights in their jobs would hold that once a person is employed, he or she "owns" that job, and it.cannot be taken by another private party. No right in property is absolute, however, and in each case where legal protection of such a right is sought, the governing legal principle must strike a balance among all of the competing rights and interests. ${ }^{175}$

In this context, on the employer's side of the balance are the employers' personal interest in the entrepreneurial freedom "independently to rearrange their businesses" and a national economic interest in the free transferability of capital. Such transferability is potentially impaired if a potential purchaser of an enterprise must anticipate being subject to legal obligations to those previously employed in the enterprise. The magnitude of these interests is probably relatively low, however, ${ }^{176}$ given the successor's opportunities to minimize the burdens of possible liability ${ }^{177}$ and the speculative nature of the feared debilitative economic effects. ${ }^{178}$

On the employees' side of the balance is the personal interest in continued employment and in the maintenance of previously agreed upon benefits, such as seniority, pension and vacation rights. In stark contrast to the ability of successors to neutralize most adverse effects, it

174. Brief for the AFL-CIO as Amicus Curiae at 10 , John Wiley \& Sons, Inc. v. Livingston, 376 U.S. 543 (1964).

175. Justice Holmes described the problem in Hudson County Water Co. v. McCarter, 209 U.S. 349, 355 (1908), as follows: "All rights tend to declare themselves absolute to their logical extreme. Yet all in fact are limited by the neighborhood of principles of policy which are other than those on which the particular right is founded, and which become strong enough to hold their own when a certain point is reached."

176. See text accompanying notes $142-53$ supra.

177. See text accompanying notes $152-53$ supra.

178. See note 153 supra and accompanying text. 
has been repeatedly recognized that employees faced with a change of ownership are generally powerless to protect their interests. ${ }^{179}$

In short, developments in labor law support the notion that an employee's interest in continued employment is a property right and suggest that the right should have judicial protection. Judicial protection of employee rights under collective agreements has taken the form of specific enforcement of arbitration clauses, ${ }^{180}$ and that remedy has sufficient flexibility to allow for a reasonable accommodation of the competing interests. ${ }^{181}$ In Howard Johnson, however, the Court's approach to the duty to hire ignored this right and, therefore, the Court did not appropriately address and balance the relevant interests. As a result, although adequate protection for employer prerogatives could be achieved with less cost to employee interests, employers have been given absolute discretion to hire a new work force and thereby abrogate the common law of the enterprise.

\section{Collective Bargaining and Collective Agreements}

In addition to reformulating the calculus of employer and employee interests in Howard Johnson, the Court was guilty of an overbroad reading of section $8(d)$ 's prohibition against forcing substantive terms on negotiating parties.

In the Burns case, the Court reasoned that:

[t]he Congressional policy manifest in the Act is to enable the parties to negotiate for any protection either deems appropriate but to allow the balance of bargaining advantage to be set by economic power realities. Strife is bound to occur if the concessions that must be honored do not correspond to the relative economic strength of the parties. ${ }^{182}$

The congressional purpose in enacting section 8(d) was to limit the reach of the National Labor Relations Board's remedial power to regulate the processes of collective bargaining. The Senate Committee report emphasized that: "the duty to bargaining collectively does not carry with it the duty to reach an agreement, because the essence of collective bargaining is that either side shall be free to decide whether proposals made to it are satisfactory." 183

On its face, then, section 8(d) was intended simply to limit the Board's control of the negotiation processes. The paradigmatic applica-

179. See text accompanying notes 22 and 49 supra.

180. See United Steelworkers v. Warrior \& Gulf Navigation Co., 363 U.S. 574 (1960).

181. See United Steelworkers v. Reliance Universal Inc., 335 F.2d 891 (3d Cir. 1964).

182. 406 U.S. at 288.

183. S. Rep. No. 573, 74th Cong., 1st Sess. 12 (1935). 
tion of the section is found in H. K. Porter Co. v. $N L R B,{ }^{184}$ where the Court refused to impose a check-off clause on an employer guilty of refusing to bargain in good faith. Noting the congressional policy behind section $8(\mathrm{~d})$, the Court held that although the National Labor Relations Board's function is to insure good faith bargaining, "it is without power to compel a company or a union to agree to any substantive contractual provision of a collective bargaining agreement."185 Since "[o]ne of [the National Labor Relations Act's] fundamental policies is freedom of contract," ${ }^{186}$ even the strong federal interest in promoting collective bargaining processes could not be reconciled with an order that might alter the relative bargaining strength of the parties. Indeed, were the Board to enforce its notion of reasonableness on the negotiating parties, the structure of labor relations would be transmuted. The limitation of government intervention in the negotiation process insures that the agreement that emerges is an acceptable accommodation of the interests of the enterprise's constituents.

In Burns, the Court held that although section 8(d) was not determinative on its face, the section's underlying policies prohibited imposing the predecessor's entire collective agreement on a successor. Read narrowly, Burns only addresses the issue of the limitations of the Board's remedial powers and leaves unanswered the question how far the Court's freedom of contract approach will be extended. The Howard Johnson Court intimated that, as a remedy, even arbitration might be contrary to the principles outlined in Burns. ${ }^{187}$ Indeed, it is hard, under the Court's analysis, to distinguish an arbitration clause from other substantive terms of a collective agreement: neither the arbitration clause nor any of the other terms is the product of economic struggle between the successor and the union. Moreover, an arbitrator's imposition of contract terms would be no more tolerable than would a court's imposition of such terms. Thus, if the Burns language is read as broadly as the Court suggested in Howard Johnson, Wiley has little vitality outside the merger context.

Although the Burns Court was rightly concerned with the policy of freedom of contract - a policy recognized in the federal labor laws ${ }^{188}$ that policy must be weighted differently where the issue is whether a successor is free to ignore a collective agreement that is the result of voluntary collective bargaining. Where the predecessor and the union have fully negotiated an agreement, it is fair to say that the freedom of

184. 397 U.S. 99 (1970).

185. Id. at 102 .

186. Id. at 108.

187. 417 U.S. at 256.

188. 406 U.S. at 281-92. 
the parties constituting the employing industry to contract has been fully recognized and that the terms represent a viable pattern of rights and obligations. This should be true any time the terms of an agreement emanate from bargaining among the parties constituting the enterprise and are not imposed by a third party. The "fairness" of the content of collective agreements is not eroded by a change in ownership, because the terms of the agreement spring from economic factors that will survive, largely unchanged. ${ }^{189}$ To argue that the economic realities that shaped the content of a particular collective agreement are greatly altered by an ownership change is to mystify the origin of the terms of the agreement and return to a contractual analysis.

As a practial matter, although the policy of freedom of contract may be compromised by court-ordered arbitration, arbitration may also positively serve other policies of the federal labor relations scheme. The collective agreement is the wellspring of the common law of the shop. ${ }^{190}$ The relationship between collective agreements and collective bargaining is not linear, however, and the substantive terms of the former have been held to be essential to the growth and persistence of trade unionism. $^{191}$ This relationship led one commentator to read the rights of organization and collective bargaining under section 7 of the National Labor Relations Act to comprehend the right to have a negotiated bargain maintained and respected. ${ }^{192}$ Arguably, in a dynamic economy a rule of law that effectively abrogates collective agreements in the successorship context would negatively influence the exercise of section 7 rights. ${ }^{193}$

The most serious impact of the Howard Johnson rule on organizing and bargaining interests will occur in those areas where unionization and collective bargaining are not firmly established. Employers can gain at least a temporary economic advantage by ousting organized

189. The factors that determine the substance of even one term of a collective agreement are so complex as to defy analysis. E. Beal \& E. Wickersham, The Practice of Collective Bargaining 155-56 (1959); H. Levinson, Determining Forces in Collective Wage Bargaining 257-77 (1966). Although it is true that the deorganization of the workplace will have a profound effect on the economic strength of the contending parties, such an approach is contradictory to the stated purposes of the National Labor Relations Act. See 29 U.S.C. \$ 151 (1970).

190. See McClintock, supra note 156 , at 55 .

191. See L. ReYNolds, supra note 168 , at 508.

192. See McClintock, supra note 156, at 63.

193. Analysis of the empirical effect of the Howard Johnson and Burns rules is outside the scope of this Comment. It may be noted that several recent Board decisions can be seen as recognizing that application of the "substantial continuity" standard of Howard Johnson to organizational contexts is not adequate to protect the organizational interests of employees. See United Maintenance \& Mfg. Co., 214 N.L.R.B. No. 31, 87 L.R.R.M. 1469 (Nov. 1, 1974); Boeing Co., 214 N.L.R.B. No. 32, 87 L.R.R.M. 1461 (Nov. 1, 1974) (Members Fanning and Penello, dissenting). 
employees, and the show of strength might cause the new employees to consider whether, by organizing, they might be trading continued employment for the exercise of their statutory rights. The mention of the possibility of a sale during an organizing campaign could affect the outcome of an election, without appearing to violate present NLRB election rules. ${ }^{104}$

In short, the enforcement of collective agreements in the successorship context does not violate the fundamental policies of section 8(d) and, properly viewed, the enforcement supports the policies favoring organization and collective bargaining. Although it is somewhat contradictory to argue that to protect the interests of employees adequately "continuity of enterprise" should be based on an analysis of the nonhuman factors involved in the corporate transition, such an approach is necessary in order to place reasonable limitations on the discretion of the successor employer while allowing employers the right to reorganize the enterprise. The enforcement of a collective agreement on any party entering the enterprise provides a governing "common law" and insures economic stability and peaceful labor relations in the successorship context; in addition, it can help promote labor organization and collective bargaining in certain sectors of the economy.

\section{III}

\section{Alternatives After Howard Johnson}

However unsatisfactory the Howard Johnson decision may have been, the law now stands that a successor is not bound to hire its predecessor's employees. Perhaps because the Court was concerned that the rule enunciated in Howard Johnson was too harsh, the Supreme Court's opinion noted some alternative remedies by which a union could protect the interests of its constituents. ${ }^{105}$ For example, if the collective agreement contains a successorship clause, the union could attempt to enjoin the sale or seek damages against the predecessor employer for its breach. In addition, there might be grounds for invoking section 8(a)(3)'s protections against anti-union hiring practices. In fact, however, although unions have been successful with these remedial alternatives in some instances, there are three distinct reasons why these

194. Resolution of the issue of the lawfulness of such a mention of possible sale would turn on the troublesome illegal threat/legitimate prophecy distinction of the Board. Chicopee Mfg. Co., 107 N.L.R.B. 106, 107 (1953). The Court has not resolved the crucial issue whether employer statements tending to discourage the exercise of section 7 rights are protected by section 8(c)-the employer "free speech provision." Compare NLRB v. TRW-Semiconductors, Inc., 385 F.2d 753 (9th Cir. 1967), with NLRB v. Sinclair Co., 397 F.2d 157 (1st Cir. 1968).

195. 417 U.S. at 262 n.8, $257-58$ \& n.3. 
alternative remedies will not generally provide effective ways for dealing with the problems of employment during succession created by the Howard Johnson rule.

\section{A. Enforcement of a "Successorship Clause"}

Justice Marshall's opinion for the majority in Howard Johnson pointed out that the union might have been able to protect its interests, prior to the sale, by seeking to enjoin the sale on the basis that it was a breach by the Grissoms of the successorship clause ${ }^{196}$ in the collective bargaining agreement. ${ }^{197}$ The successorship clause represented a promise by the Grissoms to obtain from any purchaser of the business an express agreement to abide by the labor contract then in force. The Grissoms breached this promise. In National Maritime Union v. Commerce Tankers Corp. ${ }^{198}$ for example, the union sought an injunction against the sale of a ship on which union members worked. ${ }^{199}$ The union's contract with the shipowner provided that the owner would not transfer title to the ship unless the purchasers agreed in writing to assume the obligations of the collective bargaining agreement. The appellate court noted that an injunction should have been granted because a damage recovery would have been inadequate to protect the union's interests.

Although the injunction theory is attractive, it presupposes that the union will have the foresight and the strength to negotiate the proper clause. In reality, a successorship clause deals, by definition, with a future contingency and is likely to be a bargaining chip that the union will forego in order to obtain concessions in areas of more immediate concern, such as wages, hours and working conditions. The effectiveness of an injunctive remedy is also reduced by the requirement that it be sought prior to execution of the sale. A predecessor that fails to give timely notice to the union may be able to relieve itself of the duty to compel the successor to assume the obligations of the collective agreement. Confronted with a fait accompli, the union will be unable to enforce the clause. The most ironic aspect of the injunction remedy as

196. 417 U.S. at 258 n.3. For the text of the successorship clause, see id. at 266 n.1 (dissenting opinion), quoting 482 F.2d 489, 491.

197. Id. at 258 n.3.

198. 325 F. Supp. 360 (S.D.N.Y. 1971), vacated on other grounds, 457 F.2d 1127 (2d Cir. 1972).

199. The injunction was vacated by the court of appeals on the ground that the particular successorship clause in the agreement constituted an unfair labor practice under section 8(e) of the National Labor Relations Act, 29 U.S.C. $\$ 158(\mathrm{e})$ (1970) (the so called "hot cargo" provision) because the agreement was designed to acquire work for union members as a whole and not just to preserve work for the members within the bargaining unit. 457 F.2d at 1137. 
an alternative, however, is its obvious impact on the free flow of capital and entrepreneurial discretion, the very considerations that led the Court to refuse to enforce the terms of collective agreements across ownership changes. ${ }^{200}$ Although comparative empirical effects can not be conclusively determined, the Court's suggested injunction remedy will delay or even prohibit certain transfers, while the approach suggested in this Comment would simply condition them upon arbitration. ${ }^{201}$

\section{B. Money Damages for Breach of a Successorship Clause}

A monetary award is generally acknowledged to be an inadequate remedy for loss of employment. ${ }^{202}$ Nevertheless, the Court in Howard Johnson distinguished Wiley in part by noting that the former employees in Howard Johnson, unlike those in Wiley, could assert their contract rights against the predecessor corporations because they had continued as "viable entities with substantial retained assets." ${ }^{203}$ Not only is it often the case that the predecessor either is no longer in existence or is insolvent, but the money damages remedy fails to recognize that the employee interest involved in the successorship context is the preservation of jobs. Thus, even if a money award could compensate the employees for their economic loss, it cannot adequately protect their other interests. The court in Commerce Tankers gave explicit recognition to this inadequacy:

If the defendant may simply shuck off the vessel and the collective agreement, the position of the Union (and its members) can never be restored or be accurately compensated for in money terms. The companies have deemed that hurt fully curable by their offer of a bond to make up lost pension and welfare contributions should the union ultimately win. That treats the union as some sort of business devoted to the filling of its treasury and its "funds." Whether or not unions always cleave to their ideals, this is scarcely their nature or the measure of their legal rights. Omitted from the reckoning is the heart of the matter-the interest in "the preservation of work" for its members . . . .204

\section{The Possibility of Finding a Section 8(a)(3) Violation}

Section 8(a)(3) of the National Labor Relations Act provides in part that it is an unfair labor practice for an employer "by discrimination in regard to hire or tenure of employment . . . to encourage or

200. NLRB v. Burns Int'l Security Servs., Inc., 406 U.S. 272, $287-88$ (1971).

201. See text accompanying notes 146-51 supra.

202. National Maritime Union v. Commerce Tankers Corp., 325 F. Supp. 360, 366

(S.D.N.Y. 1971), vacated on other grounds, 457 F.2d 1127 (2d Cir. 1972).

203. 417 U.S. at 257.

204. 325 F. Supp. at 366. 
discourage membership in any labor organization . . .."205 A successor who refuses to hire its predecessor's employees solely because they are union members, or who purposely hires only a minority of its predecessor's organized employees in order to avoid having to recognize and bargain with the union, unquestionably comes within the statutory proscription. ${ }^{206}$ The vital question under this third alternative remedy is what degree of proof of purposeful discrimination is necessary under the statute. The rest of this Comment examines the cases involving section 8(a)(3) unfair labor practices in a successorship context in order to outline the difficult evidentiary requirements which must be met in order to establish a section 8(a)(3) violation.

In NLRB v. New England Tank Industries, Inc. ${ }^{207}$ a successor's refusal to hire its predecessor's employees was held to be a section 8(a)(3) violation. The finding was based primarily on the testimony of several former employees who, upon application for employment with the successor, were told by the company's hiring agent that the company "didn't want any union men there" and that the company wanted to "break the union." 208 Moreover, the company admitted that it was normal procedure for the successor in that particular industry to retain the personnel of the prior contractor. The court noted that:

[d]espite the presence of a pool of experienced workers, respondent went to considerable length to replace the union employees with entirely new workers-most of whom had no previous experience on pipeline operations. Indeed, to train the new workers, respondent transported some employees from as far away as its California operations. ${ }^{209}$

The court also recognized that all of the successor's "far flung affiliates function as 'non-union' operations." ${ }^{210}$ The totality of this evidence showed a section $8(a)(3)$ violation because "the substantial or motivating reason" for the successor's refusal to hire the former employees was the fact that they were union members. ${ }^{211}$

In K.B. \& J. Young's Super Markets, Inc. v. NLRB, ${ }^{212}$ the Ninth Circuit Court of Appeals ordered enforcement of an NLRB reinstatement order which included back pay. In Young, the successor was

205. 29 U.S.C. $\$ 158(a)(3)(1970)$.

206. See Howard Johnson Co. v. Detroit Local Joint Exec. Bd., 417 U.S. 249, 262 n.8 (1974); NLRB v. Burns Int'l Security Servs., Inc., 406 U.S. 272, 280 n.5 (1972); K.B. \& J. Young's Super Markets, Inc. v. NLRB, 377 F.2d 463 (9th Cir. 1967), cert. denied, 389 U.S. 841 (1967).

207. 302 F.2d 273 (1st Cir. 1962), cert. denied, 371 U.S. 875 (1962).

208. Id. at $275-76$.

209. Id. at 276.

210. Id.

211. Id. at 277 .

212. 377 F.2d 463 (9th Cir. 1967), cert. denied, 389 U.S. 841 (1967). 
found to have violated section $8(a)(3)$ because it caused the predecessor to discharge its employees for anti-union reasons. The trial examiner found that all the meat department employees had been fired because of the successor's desire to "evade and escape its obligations as a successor . . . to recognize and bargain with the Union . . .."213 There was evidence, apart from the mass discharge itself, of anti-union discrimination by the successor in its hiring practices. The successor offered to hire one former employee but then denied her employment when she refused to withdraw from the union. Another employee, who had been transferred from the single affiliated union store after the sale, was discharged shortly after he admitted belonging to the union. These acts constituted separate section $8(a)(3)$ violations as to the individual workers. $^{214}$

The court of appeals decreed enforcement of the reinstatement order, finding that there was clear support in the record for the National Labor Relations Board's finding that unlawful discharge was involved. $^{215}$ The court's decision was based in part upon the conclusion that Wiley implied that the right to continued employment did not automatically terminate upon the change in ownership but was among "potentially bargainable issues," Howard Johnson. ${ }^{217}$ The court in Young relied mainly upon the Board's finding that the successor's insistence upon the mass discharge was motiviated by anti-union sentiment. Since this unfair labor practice justified retroactive reinstatement, the requisite continuity in identity of work force was present. ${ }^{218}$

In NLRB v. Foodway of El Paso, ${ }^{219}$ decided 2 weeks after Howard Johnson was decided, a successor was held to have committed a section 8(a)(3) violation by refusing to hire its predecessor's non-supervisory employees because of their union membership. The predecessor had owned three retail grocery stores, two of which were non-union. The successor obtained the two non-union stores in one transaction. All the employees of these stores, managerial and rank-and-file, were rehired, and operations were commenced immediately without change. In the separately purchased union store, however, the successor hired only the managerial employees; the predecessor had discharged all the rankand-file employees just prior to the sale. The successor instituted what

213. K.B. \& J. Young's Super Markets, Inc., 157 N.L.R.B. 271, 278 (1966).

214. Id. at 276-78.

215. 377 F.2d at 466 .

216. Id.

217. Howard Johnson, however, did not present a claim of anti-union discrimination in hiring. 417 U.S. at 262 n.8.

218. 377 F.2d at 465 .

219. 496 F.2d 117 (5th Cir. 1974). 
the court termed "some unremarkable physical changes" before reopening the store a month later. ${ }^{220}$ Thirteen out of the seventeen former unionized employees unsuccessfully sought employment with the new owner, and two others did not even apply because they "learned that it would be futile to do so." 221 The successor instead "hired all new employees, many of whom were inexperienced and required training."222 They were paid lower wages than the union scale. The successor argued that the employees' union membership was not the reason why they were not retained. It stressed that the store was losing money before the changeover, that none of the former employees were told that they were not going to be hired because they were union members, and that the store was closed for remodeling and thus no jobs were available. ${ }^{223}$

The court was not persuaded. It cited the following facts in support of its holding that the employees had suffered unlawful discrimination: (1) the successor was aware of the union contract before the purchase; (2) all former employees were hired at the two non-union stores; (3) inexperienced workers were hired to replace experienced workers despite one worker's offer to take a wage cut; and (4) the former employees of the union store were denied consideration even for jobs in the other two non-union stores. ${ }^{224}$ The court dismissed the successor's argument that refusal to hire was the result of a legitimate business consideration-the store's loss of revenues-with the observation that the losses were the responsibility of the retained managerial employees. ${ }^{225}$

An examination of the factual pattern of these cases suggests that mere evidence of the mass discharge of a predecessor's employees is not sufficient to establish that section $8(a)(3)$ has been violated as to all the employees. Indeed, the Court's discussion of section 8(a)(3) in Howard Johnson-where the successor expressly refused to be bound by the collective agreement between the predecessor and the union and told the predecessor that it desired to proceed with its independent work forcesupports that conclusion. The predecessor in Howard Johnson fired all its employees and Howard Johnson rehired only a small minority of them. In noting that no suggestion of anti-union motivation had been

220. Id. at 118. Renovation of the building, installation of some new machinery, and restocking of the shelves with different products were among 24 factors suggested by the purchaser Foodway to support its unsuccessful contention that it could not be held to be a "successor." Id. at 120-21.

221. Id. at 118 .

222. Id.

223. Id. at 119.

224. Id. at 119-20.

225. Id. at 119. 
made regarding Howard Johnson's hiring policies, the Court reiterated its rule that in the absence of positive evidence of anti-union motives, the existence of an 8(a)(3) violation turns on the isolation of a union nexus as the sole explanation of differential treatment. ${ }^{228}$

The critical question in utilizing section $8(a)(3)$ is what evidence, other than a mass discharge, is necessary to prove a violation. The peculiar facts present in the case just discussed show the limits of section 8(a)(3) for dealing with the inequities under the Howard Johnson rule. Absent express admission of anti-union motives such as those found in the New England Tank case, it is doubtful that violations will be found. A court might consider a company's pattern of hiring during prior takeovers, but clear factual backgrounds seldom exist. Similarly, a situation like Foodway, in which an employer simultaneously purchased union and anti-union concerns, will rarely be duplicated. Only Young presents a pattern-the presence of individual section 8(a)(3) violations providing evidence of the broader violation-likely to be repeated. Even in Young, however, the employer could have avoided the result if it had realized that there was no need to refuse to hire the two union members since they probably could not have commanded the majority necessary to demand recognition of the union as a bargaining agent. At worst, they might later have sought to organize the other workers.

In short, the factual situations surrounding corporate takeovers will seldom be sufficient to generate clear evidence of anti-union motivation. As long as employers do not trumpet their desire to avoid dealing with the union during the takeover period, they will be able to hide their intentions behind the broad grant of hiring discretion given them in Howard Johnson.

\section{CONCLUSION}

Although the Supreme Court in Howard Johnson enunicated a test that, on its face, would have refined the analysis used by courts in the successorship context, its application of the "interest analysis" test-so as to require substantial continuity in the workforce across changes of ownership-severely attenuated the successorship doctrine that had emerged in Wiley. Specifically, the Court failed to analyze the duty to hire in the concrete fashion that its interest analysis seemed to require. The Court's absolute deference employer prerogative overstated the need for unilateral decisionmaking by management and sacrificed those interests-both public and private-that the successorship doctrine was devised to protect.

226. 417 U.S. at $262 \&$ n.8. 
By allowing successor-employers unilaterally to determine their labor law obligations simply by monitoring the size of the employee contingent inherited from the predecessor, the Court created a rule that seems to destroy the practical effect of the successor doctrine. Had the Court required that the constituents of the enterprise arbitrate this unanticipated dispute it would have allowed a flexible and realistic resolution of the competing interests. Not only practical necessity, but also the nature of the problem favored such a disposition. 